ORNL/TM-12831

\title{
Neutron Dosimetry of the HFIR Hydraulic Facility
}

\author{
S. T. Mahmood, S. Mirzadeh, K. Farrell,
}

J. V. Pace III, and B. M. Oliver

Date Published: February 1995

NOTICE: This document contains information of a preliminary nature. It is subject to revision or correction and therefore does not represent a final report.

Prepared for the

U.S. Department of Energy

Office of Basic Energy Sciences

KC 0201040

\author{
Prepared by the \\ OAK RIDGE NATIONAL LABORATORY \\ Oak Ridge, Tennessee 37831 \\ managed by \\ MARTIN MARIETTA ENERGY SYSTEMS, INC. \\ for the \\ U.S. DEPARTMENT OF ENERGY \\ under contract DE-AC05-84OR21400
}

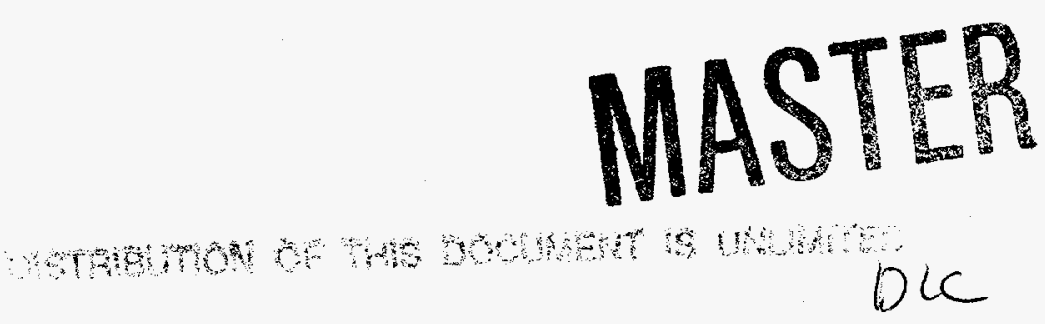




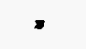




\section{DISCLAIMER}

This report was prepared as an account of work sponsored by an agency of the United States Government. Neither the United States Government nor any agency thereof, nor any of their employees, make any warranty, express or implied, or assumes any legal liability or responsibility for the accuracy, completeness, or usefulness of any information, apparatus, product, or process disclosed, or represents that its use would not infringe privately owned rights. Reference herein to any specific commercial product, process, or service by trade name, trademark, manufacturer, or otherwise does not necessarily constitute or imply its endorsement, recommendation, or favoring by the United States Government or any agency thereof. The views and opinions of authors expressed herein do not necessarily state or reflect those of the United States Government or any agency thereof. 


\section{DISCLAIMER}

Portions of this document may be illegible in electronic image products. Images are produced from the best available original document. 


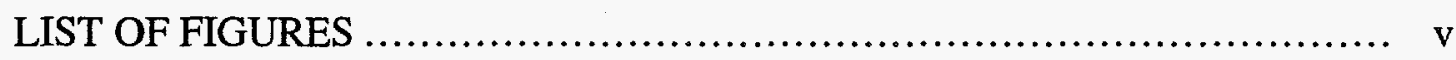

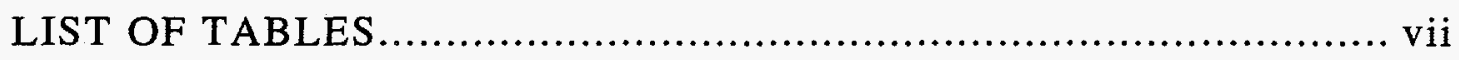

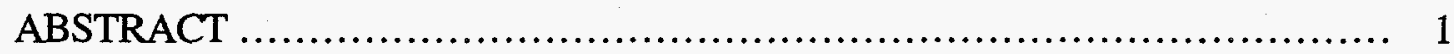

1. INTRODUCTION....................................................... 1

2. EXPERIMENTAL DETAILS................................................ 2

2.1 IRRADIATION FACILITY ........................................... 2

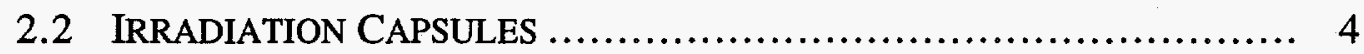

2.3 SELECTION OF MONITORS ............................................ 4

2.4 IRRADIATION SCHEDULE.......................................... 7

2.5 ACTIVITY MEASUREMENTS ON ACTIVATION AND FISSION MONITORS ................................................ 9

2.6 HELIUM MEASUREMENTS ON HAFMS................................... 9

3. DATA ANALYSIS AND RESULTS .................................. 11

3.1 DETERMINATION OF REACTION RATES........................... 11

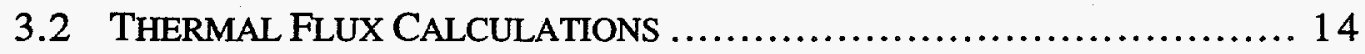

3.3 TOTAL AND Fast FluX CALCUlations ........................... 15

4. DISCUSSION AND CONCLUSIONS ................................ 20

5. ACKNOWLEDGMENTS ................................................ 30

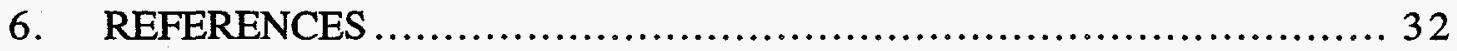




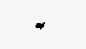




\section{LIST OF FIGURES}

Figure

1 The central target region of the High Flux Isotope Reactor. The hydraulic tube is located in position B3.

2 The finned aluminum capsule used to irradiate the flux monitors (all dimensions are in millimeters).

3 The calculated target region volume-integrated neutron energy spectrum normalized to one fission neutron....................................18

4 Measured neutron flux profiles along the length of the hydraulic tube.

5 Some important neutron flux ratios along the length of the hydraulic tube. 



\section{LIST OF TABLES}

Table

1 Selected reactions and monitor materials 6

2 Irradiation schedule 8

3 Activation and fission monitors product nuclide data 10

$4 \quad$ Saturation activities of the bare activation and helium accumulation monitors and $\mathrm{Cd}$-covered fission monitors.

5 Saturation activities of the bare and Cd-covered thermal flux monitors

6 Parameters used in thermal flux calculations. 15

7 Sixty-four group HFIR aluminum target region total volumeintegrated neutron spectrum normalized to one fission neutron

8 One-group volume-integrated beginning-of-cycle cross sections (reaction or production) averaged over spectrum in the HFIR target region

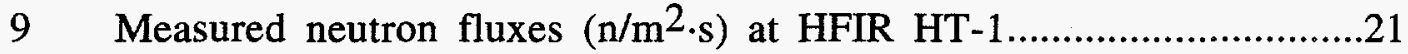

10 Measured neutron fluxes $\left(\mathrm{n} / \mathrm{m}^{2} \cdot \mathrm{s}\right)$ at HFIR HT-3.............................22

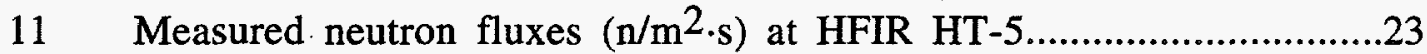

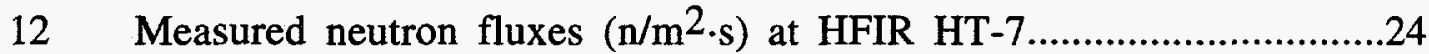

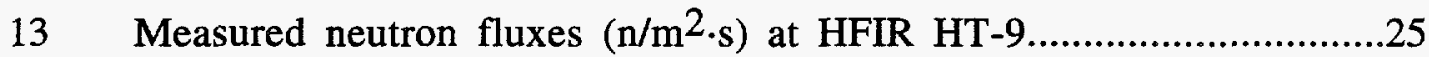

14 Average values of the measured neutron fluxes $\left(\mathrm{n} / \mathrm{m}^{2} \cdot \mathrm{s}\right)$ in the

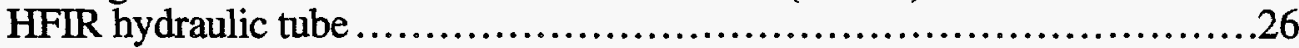

15 Measured flux ratios in the HFIR hydraulic tube........................26

16 Comparison of the fluxes, $\mathrm{n} / \mathrm{m}^{2} \cdot \mathrm{s}\left(\mathrm{x}_{10} 0^{19}\right)$, in the hydraulic tube with earlier measurements 1,2 made at $100-\mathrm{MW}$ power 


\title{
Neutron Dosimetry of the HFIR Hydraulic Facility*
}

\author{
S. T. Mahmood ${ }^{\dagger}$, S. Mirzadeh, K. Farrell, \\ J. V. Pace III, and B. M. Oliver
}

\begin{abstract}
The total, fast, and thermal neutron fluxes at five axial positions in the High Flux Isotope Reactor (HFIR) hydraulic tube have been measured using bare and/or cadmiumcovered activation, fission, and helium accumulation flux monitors. The spectrumaveraged, one-group cross sections over selected energy ranges for the reactions used in the measurements were obtained using cross sections from the ENDF/B-V file, and the target region volume-integrated spectrum was calculated with DORT, a two-dimensional discrete ordinates radiation transport code. The fluxes obtained from various monitors are in good agreement. The total and fast $(>1 \mathrm{MeV})$ neutron fluxes vary from $1.6 \times$ $10^{19} \mathrm{n} / \mathrm{m}^{2} \cdot \mathrm{s}$ and $1.6 \times 10^{18} \mathrm{n} / \mathrm{m}^{2} \cdot \mathrm{s}$, respectively, at the ends (HT-1 and -9 ) of the facility to $4.0 \times 10^{19} \mathrm{n} / \mathrm{m}^{2} \cdot \mathrm{s}$ and $4.6 \times 10^{18} \mathrm{n} / \mathrm{m}^{2} \cdot \mathrm{s}$, respectively, at the center (HT-5) of the facility. The thermal-to-fast $(>1 \mathrm{MeV})$ flux ratio varies from about 5.4 at the center to about 6.7 at the ends of the facility. The ratio of fast flux greater than $0.1 \mathrm{MeV}$ to that greater than $1 \mathrm{MeV}$ is 2.0 and stays almost constant along the length of the tube.
\end{abstract}

\section{INTRODUCTION}

The Oak Ridge National Laboratory (ORNL) High Flux Isotope Reactor (HFIR) is a compact, flux trap-type reactor with the capability and facilities for performing a wide variety of irradiations. The trap at the center of the cylindrical core of the HFIR is filled by

\footnotetext{
${ }^{*}$ Research supported by the Division of Materials Science, U.S. Department of Energy under contract DE-AC05-840R21400 with Martin Marietta Energy Systems, Inc. One of the authors (S. T. Mahmood) was supported by an appointment to the Oak Ridge National Laboratory Postdoctoral Research Program administered by the Oak Ridge Institute for Science and Education.

†Present address: General Electric Company, Vallecitos Nuclear Center, Pleasanton, CA 94566.

‡Rockwell International, Canoga Park, CA 91309.
} 
a bundle of aluminum target tubes that hold curium-base materials for production of transuranic elements. These tubes are normally accessible only during fuel changes. A single tube, known as the hydraulic tube facility, passes completely through the bundle and exits the reactor. It conducts a train of small capsules, or rabbits, in and out of the core on demand. The train is driven by hydraulic pressure. The hydraulic tube is in constant use for a variety of purposes, principally for production of isotopes for medical applications.

The neutron fluxes in the trap are not only very high, about $10^{19} \mathrm{n} / \mathrm{m}^{2} \cdot \mathrm{s}$, they are steady during most of the 21-d fuel cycle, and they are reproduced from one cycle to another. The neutron fluxes along the length of the rabbit train were measured carefully about 20 years ago, 1,2 and those data have provided a basis from which a required neutron exposure at any level in the train can be achieved by control of exposure time alone. However, some changes have been implemented in the trap region since the late 1980s. The reactor operating power has been reduced from 100 to $85 \mathrm{MW}$, and the hydraulic tube which formally occupied the central position in the target bundle has been moved to a different position. Transuranium production is now more stringent and many of the target positions are occupied by a materials irradiation facility and by aluminum dummy targets. These changes will have altered the availability of neutrons in the trap. Consequently, the fluxes in the hydraulic tube need to be redetermined. A reliable flux and spectrum profile is needed, also, to support a new program of radiation embrittlement studies of ferritic steels utilizing the hydraulic tube facility. Accordingly, we have performed comprehensive neutron dosimetry of the hydraulic tube facility using refined activation techniques, cross section data bases, and calculational methods.

\section{EXPERIMENTAL DETAILS}

\subsection{IRRADIATION FACILITY}

The irradiations were performed in the HFIR hydraulic tube which is located in position B3 of the target region as shown in Fig. 1. This irradiation facility accommodates nine rabbit capsules, one on top of the other, in a $500-\mathrm{mm}$ stack with position HT-1 at the bottom, level with the bottom of the reactor core, and HT-9 at the top, corresponding to the top of the core. The vertical center of the HT-5 position coincides with the horizontal center line of the core. Loading and unloading of the capsules during reactor operation is carried out by controlling the direction of flow of the cooling water through the tube. The 


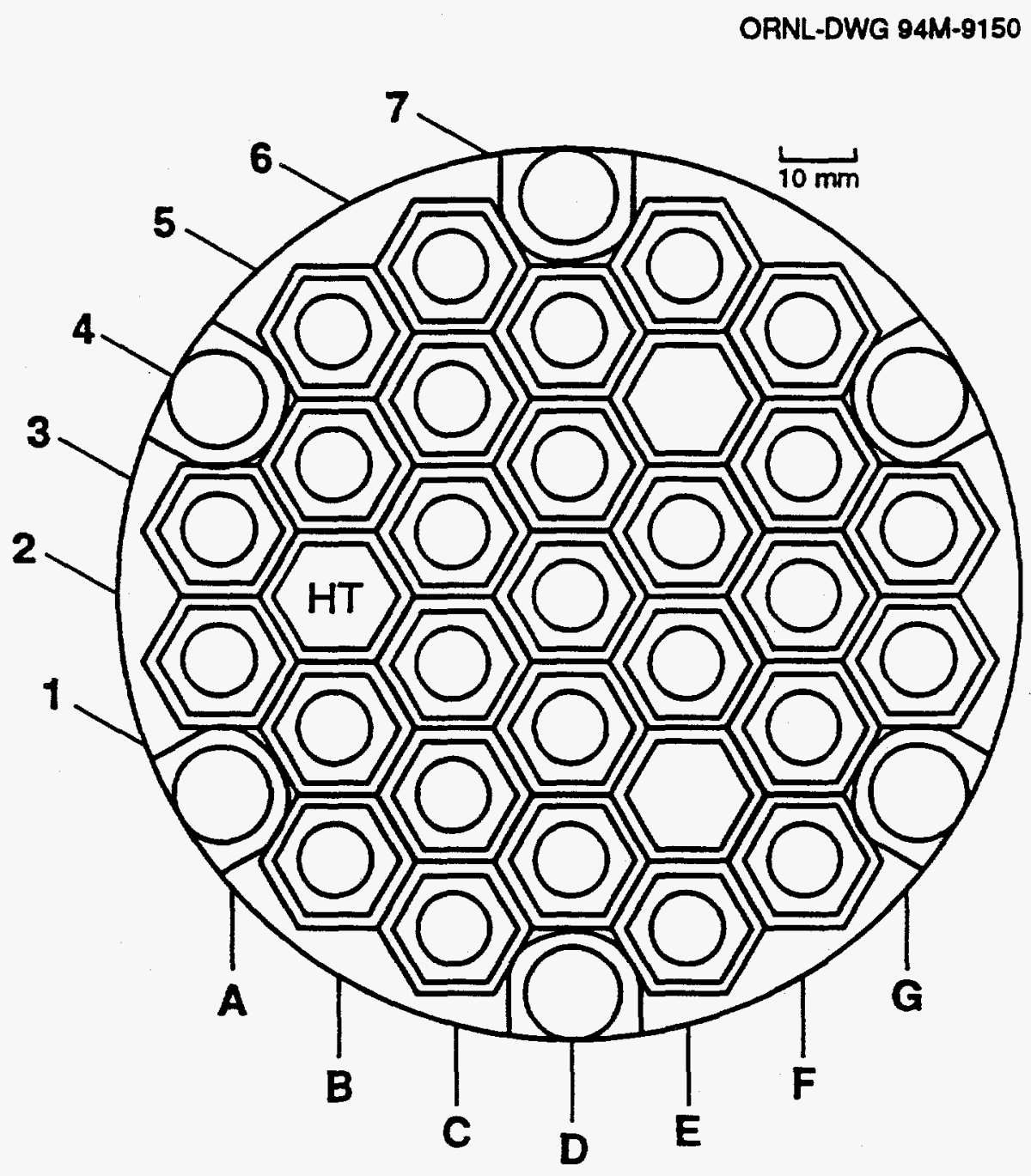

Fig. 1. The central target region of the High Flux Isotope Reactor. The hydraulic tube is located in position B3. 
capsules can be either standard finned aluminum cans that are completely sealed or perforated capsules to allow water cooling of the specimens inside.

\subsection{IRRADIATION CAPSULES}

The capsule material and design used for irradiating the flux monitors were the same as the standard capsule used by the Nuclear Medicine Group in their routine irradiations in the hydraulic tube. The capsules were made according to the drawing shown in Fig. 2, using finned tubing of 6061 aluminum. The ends of the capsules were sealed by welding in end plugs. One end of each capsule was sealed before loading the monitors while the other end was sealed afterwards. Some monitors were shielded with cadmium vials to block out thermal neutrons. Unshielded, or bare, monitors were wrapped in aluminum foil and were loaded at the center of each capsule using aluminum foil spacers at each end. Capsules that contained both bare and Cd-covered monitors had three spacers, one at each end and one in between the bare and $\mathrm{Cd}$-covered monitors.

\subsection{SELECTION OF MONITORS}

In order to cover as much of the neutron energy range as possible, a number of activation, fission, and helium accumulation monitors were selected. The selection of the monitors was determined by purity of the material, natural abundance and activation cross section of the target isotope, half-life and decay scheme of the product nuclide, burn-out and burn-in of the nuclides, material stability in a radiation environment, heat generation and removal characteristics, and reactivity effects.

Table 1 gives a listing of the selected monitor materials, reactions, abundance of the target isotopes, threshold energies for fast monitors, and thermal neutron activation cross sections for thermal flux monitors. The activation monitors used in this experiment can be divided into two categories, fast flux monitors and thermal flux monitors. Wires of $\mathrm{Al}, \mathrm{Ti}$, $\mathrm{Fe}, \mathrm{Ni}$, and $\mathrm{Cu}$ were used as fast flux monitors; $\mathrm{Co}, \mathrm{Ag}$, and dilute alloys of $\mathrm{Co}, \mathrm{Ag}$, and $\mathrm{Au}$ in aluminum were thermal flux monitors. All of these monitors, except pure Ag, were in the form of high-purity wires with diameters ranging from 0.25 to $0.75 \mathrm{~mm}$ and lengths varying from 2 to $50 \mathrm{~mm}$; pure Ag was in the form of 0.025 -mm-thick foil. The thermal flux monitors, $\mathrm{Au}, \mathrm{Ag}$, and $\mathrm{Co}$, were irradiated bare as well as inside $\mathrm{Cd}$ filters. The purpose of the cadmium filters was to discriminate epi- and sub-cadmium flux values. The $\mathrm{Au}-\mathrm{Al}$, pure $\mathrm{Al}, \mathrm{Ag}-\mathrm{Al}, \mathrm{Co}-\mathrm{Al}$, pure $\mathrm{Cu}$, and pure Ti monitors were acquired from Reactor Experiments, Inc., while pure $\mathrm{Fe}$ and Ni monitors were obtained from Materials Research Corporation. 

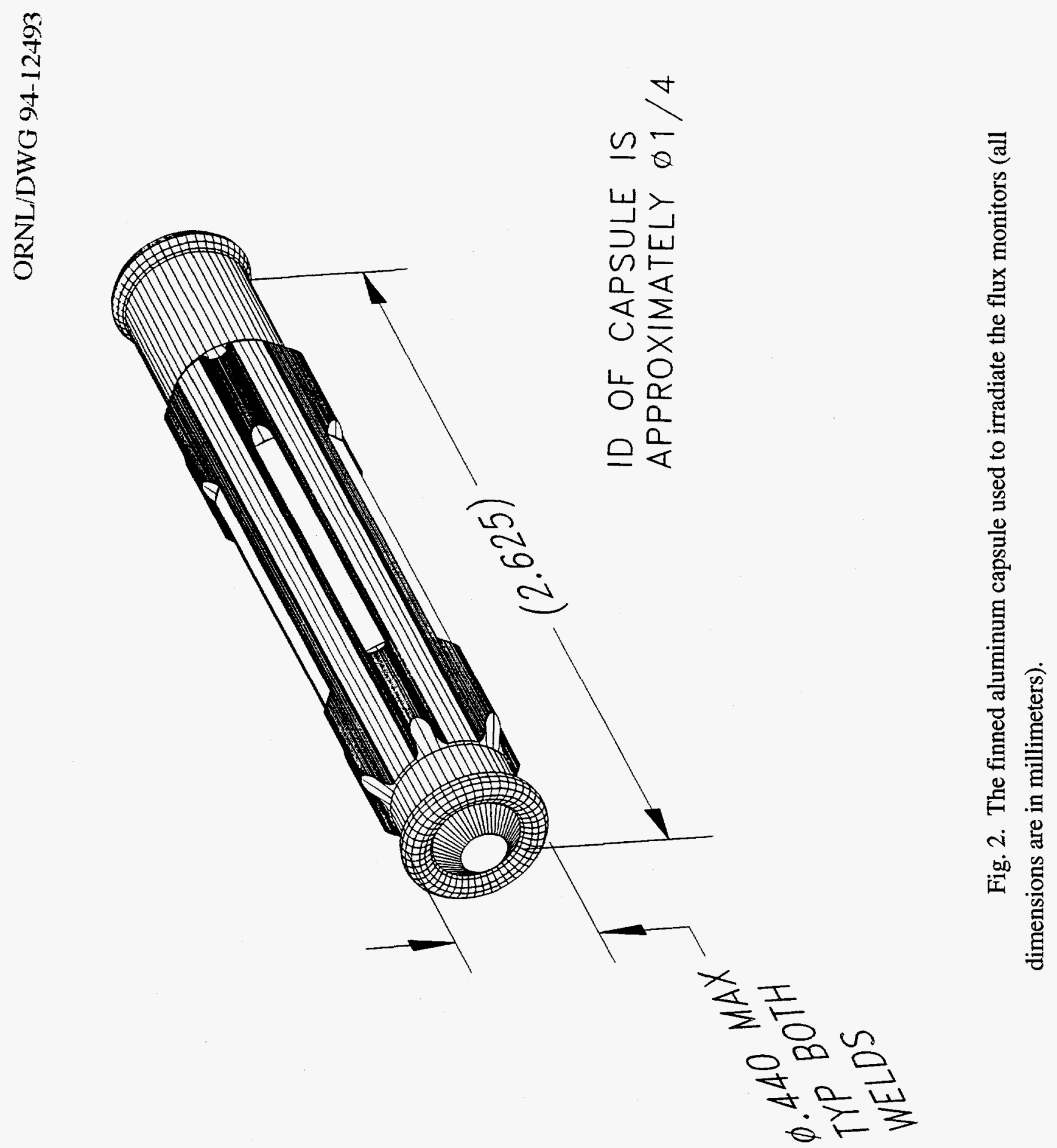
Table 1. Selected reactions and monitor materials

\begin{tabular}{|c|c|c|c|c|}
\hline Reaction & Material & Physical form & $\begin{array}{l}\text { Target isotope } \\
\text { abundance }(\%)\end{array}$ & $\begin{array}{c}\text { Threshold energy } \\
(\mathrm{MeV})\end{array}$ \\
\hline${ }^{27} \mathrm{Al}(\mathrm{n}, \alpha){ }^{24} \mathrm{Na}$ & $99.999 \% \mathrm{Al}$ & 0.75 -mm-diam wire & 100 & 6.5 \\
\hline${ }^{46} \mathrm{Ti}(\mathrm{n}, \mathrm{p})^{46} \mathrm{Sc}$ & $99.793 \% \mathrm{Ti}$ & 0.50 -mm-diam wire & 7.99 & 3.8 \\
\hline${ }^{54} \mathrm{Fe}(\mathrm{n}, \mathrm{p}){ }^{54} \mathrm{Mn}$ & $99.99 \% \mathrm{Fe}$ & 0.50 -mm-diam wire & 5.84 & 2.3 \\
\hline${ }^{58} \mathrm{Ni}(\mathrm{n}, \mathrm{p}){ }^{58} \mathrm{Co}$ & $99.951 \% \mathrm{Ni}$ & 0.50-mm-diam wire & 67.90 & 2.1 \\
\hline${ }^{63} \mathrm{Cu}(\mathrm{n}, \alpha){ }^{60} \mathrm{Co}$ & $99.999 \% \mathrm{Cu}$ & 0.75-mm-diam wire & 69.17 & 4.7 \\
\hline${ }^{237} \mathrm{~Np}(\mathrm{n}, \mathrm{f}){ }^{140} \mathrm{Ba}$ & ${ }^{237} \mathrm{NpMgO}$ & sealed in a V capsule & 100 & 0.67 \\
\hline${ }^{9} \mathrm{Be}(\mathrm{n}, \mathrm{He})$ & $99.99 \% \mathrm{Be}$ & small chunks & 100 & $\begin{array}{c}2.5 \\
\underline{\sigma}_{0} \text { (barns) }\end{array}$ \\
\hline${ }^{197} \mathrm{Au}(\mathrm{n}, \gamma){ }^{198} \mathrm{Au}$ & $0.058 \% \mathrm{Au}-\mathrm{Al}$ & 0.25 -mm-diam wire & 100 & 98.8 \\
\hline${ }^{59} \mathrm{Co}(\mathrm{n}, \gamma){ }^{60} \mathrm{Co}$ & $\begin{array}{l}0.66 \% \mathrm{Co}-\mathrm{Al} \\
99.514 \% \mathrm{Co}^{a}\end{array}$ & $\begin{array}{l}0.75 \text {-mm-diam wire } \\
0.50 \text {-mm-diam wire }\end{array}$ & 100 & 37.45 \\
\hline${ }^{109} \mathrm{Ag}(\mathrm{n}, \gamma){ }^{110 \mathrm{~m}} \mathrm{Ag}$ & $\begin{array}{l}0.145 \% \mathrm{Ag}-\mathrm{Al} \\
99.999 \% \mathrm{Ag}^{a}\end{array}$ & $\begin{array}{l}0.50-\mathrm{mm} \text {-diam wire } \\
0.025 \mathrm{~mm} \text { thick foil }\end{array}$ & 48.65 & 4.1 \\
\hline${ }^{6} \mathrm{Li}(\mathrm{n}, \mathrm{He})$ & $0.705 \% \mathrm{Li}-\mathrm{Al}$ & 0.50 -mm-diam wire & 7.42 & 942 \\
\hline${ }^{10} \mathrm{~B}(\mathrm{n}, \mathrm{He})$ & $0.502 \% \mathrm{~B}-\mathrm{Al}$ & 0.50 -mm-diam wire & 19.58 & 3838 \\
\hline
\end{tabular}

$a_{\text {Used in }} \mathrm{Cd}$ covers. 
In order to provide confirmatory measurements of fast flux from a different type of monitor, conventional fission monitors of ${ }^{237} \mathrm{~Np}$ were also included. The $\mathrm{Np}$ was in the form of ${ }^{237} \mathrm{NpMgO}$ sealed in a small welded vanadium capsule. This was an off-the-shelf monitor from a production batch that has supplied such monitors for many dosimetry experiments including the recent "DOS" series of HFIR pressure-vessel dosimetry experiments. 3,4 Because ${ }^{237} \mathrm{~Np}$ has a very high thermal neutron capture cross section, the monitor was encapsulated in a Cd tube with $0.75-\mathrm{mm}$ wall thickness.

Non-activation and non-fission-type dosimeters were also used in this experiment. These are helium accumulation flux monitors (HAFMs) described in American Society for Testing and Materials (ASTM) Standard E910-89 (ref. 5). Neutron absorption in these monitors produces helium, which is a stable reaction product that can be measured with high accuracy. The HAFMs chosen for this experiment were ${ }^{9} \mathrm{Be},{ }^{6} \mathrm{Li}$, and ${ }^{10} \mathrm{~B}$. The ${ }^{9} \mathrm{Be}$ is a fast flux monitor. It has several helium-producing reactions, a minor one with a threshold of about $0.7 \mathrm{MeV}$ and a major one with a threshold of $2.5 \mathrm{MeV}$. This monitor was in the form of small chips. The ${ }^{6} \mathrm{Li}$ and ${ }^{10} \mathrm{~B}$ are thermal neutron monitors. These monitors were in the form of $0.5-\mathrm{mm}$-diam wires of $0.705 \% \mathrm{Li}-\mathrm{Al}$ and $0.502 \% \mathrm{~B}-\mathrm{Al}$. These HAFMs were provided by Rockwell International Corporation from their pedigreed stock.

\subsection{IRRADIATION SCHEDULE}

In the first set of irradiations (see Table 2), five capsules were prepared with identity marks NM-192 through -196 . There were three packages in each capsule. The packages were made by wrapping the monitors in $0.05-\mathrm{mm}$-thick aluminum foil. The package $\mathrm{A}$ in each capsule contained $\mathrm{Au}-\mathrm{Al}$ and pure $\mathrm{Al}$ wires; package $\mathrm{B}$ contained $\mathrm{Ag}-\mathrm{Al}$, $\mathrm{Co}-\mathrm{Al}, \mathrm{Ni}, \mathrm{Fe}, \mathrm{Cu}$, and Ti; package $\mathrm{C}$ in capsules NM-192 through -194 contained Al-B, $\mathrm{Al}-\mathrm{Li}$, and Be monitors, while package $\mathrm{C}$ in capsules NM-195 and -196 contained only Al$\mathrm{B}$ and $\mathrm{Al}-\mathrm{Li}$ wires. These capsules were irradiated in positions HT-1,-3,-5,-7, and -9 according to the schedule given in Table 2 . All capsules were irradiated simultaneously for $1 \mathrm{~h}$ at full reactor power of $85 \mathrm{MW}$.

In the second set, two capsules (NM-197 and -198) were prepared. Each capsule contained bare and cadmium-covered $\mathrm{Au}, \mathrm{Ag}$, and Co monitors, and a cadmium-covered $\mathrm{Np}$ monitor. The bare $\mathrm{Au}, \mathrm{Ag}$, and $\mathrm{Co}$ monitors were wrapped in aluminum foil while $\mathrm{Cd}-$ covered monitors were in a $\mathrm{Cd}$ cylinder with a 1.14-mm-thick and 8.64-mm-high wall and a plug-in cap on the top (ORNL Drawing No. M-12175-CP-939E). The cylinder fitted in the capsule with very small clearance. The Np monitors, sealed in welded vanadium capsules, were inside 0.75 -mm-thick cadmium tubing. The capsules NM-197 and -198 
Table 2. Irradiation schedule

\begin{tabular}{|c|c|c|c|c|c|c|}
\hline Capsule & Monitors/filter & $\begin{array}{c}\mathrm{HT} \\
\text { location }\end{array}$ & $\begin{array}{l}\text { Power } \\
\text { (MW) }\end{array}$ & Irr. time & Date & $\begin{array}{l}\text { HFIR } \\
\text { irr. \# }\end{array}$ \\
\hline NM-192 & $\begin{array}{c}\mathrm{Au}, \mathrm{Al}, \mathrm{Ag}, \mathrm{Co}, \mathrm{Ni}, \mathrm{Fe}, \\
\mathrm{Cu}, \mathrm{Ti}, \mathrm{B}, \mathrm{Li}, \mathrm{Be} / \mathrm{bare}\end{array}$ & 1 & 85 & $1 \mathrm{~h}$ & 23 Feb., '92 & $2-92-5^{b}$ \\
\hline NM-193 & $"$ & 3 & 85 & $1 \mathrm{~h}$ & $"$ & $2-92-6^{b}$ \\
\hline NM-194 & " & 5 & 85 & $1 \mathrm{~h}$ & $"$ & $2-92-7 b$ \\
\hline NM-195 & $\begin{array}{c}\mathrm{Au}, \mathrm{Al}, \mathrm{Ag}, \mathrm{Co}, \mathrm{Ni} \\
\mathrm{Fe}, \mathrm{Cu}, \mathrm{Ti}, \mathrm{B}, \mathrm{Li} / \mathrm{bare}\end{array}$ & 7 & 85 & $1 \mathrm{~h}$ & & $2-92-8^{b}$ \\
\hline NM-196 & " & 9 & 85 & $1 \mathrm{~h}$ & $"$ & $2-92-9 b$ \\
\hline NM-197 & $\begin{array}{c}\mathrm{Au}, \mathrm{Ag}, \mathrm{Co} / \\
\text { bare \& Cd covered } \\
+\mathrm{Np} / \mathrm{Cd} \text { covered }\end{array}$ & 1 & 10.57 & $1 \mathrm{~h}$ & 1 May, '92 & $4-92-4 c$ \\
\hline NM-198 $a$ & $\begin{array}{c}\mathrm{Au}, \mathrm{Ag}, \mathrm{Co} / \\
\text { bare \& Cd covered } \\
+\mathrm{Np} / \mathrm{Cd} \text { covered }\end{array}$ & 5 & 10.57 & $1 \mathrm{~h}$ & $"$ & $4-92-5^{c}$ \\
\hline NM-200 & $\begin{array}{c}\mathrm{Au}, \mathrm{Ag}, \mathrm{Co} / \\
\text { bare \& Cd covered }\end{array}$ & 5 & 8.85 & $1 \mathrm{~h}$ & 21 Nov., '92 & $10-92-2^{d}$ \\
\hline
\end{tabular}

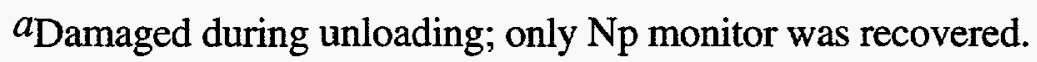

$b_{\text {HFIR cycle } 305 .}$

cHFIR cycle 307.

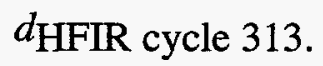


were irradiated in positions HT-1 and -5 , respectively, for $1 \mathrm{~h}$ at a power level of 10.57 MW during startup of the reactor. The reduced power level was used to avoid any excessive heating of the $\mathrm{Cd}$ filters. The measured activities were normalized to the full reactor power of $85 \mathrm{MW}$.

Only the Np monitor was recovered from the NM-198 capsule, the others being inadvertently damaged during unloading of the capsule in the hot cell. Therefore, another capsule, NM-200, was prepared that contained bare and cadmium-covered $\mathrm{Au}, \mathrm{Ag}$, and $\mathrm{Co}$ monitors. This capsule was irradiated in position HT-5 of the hydraulic tube for $1 \mathrm{~h}$ at 8.85 MW. The measured activities of these monitors were also normalized to the full reactor power.

\subsection{ACTIVITY MEASUREMENTS ON ACTIVATION AND FISSION MONITORS}

Gamma rays emitted by the activation and fission products of the monitors were used to measure the induced activities. Table 3 gives half-lives of the product nuclides and energies and decay fractions of the gamma rays that were counted. A lithium-drifted germanium detector [Ge(Li)], connected to a personal computer-based multichannel analyzer, was used for these measurements. The detector was enclosed in a lead shield, and the source-to-detector distance was maintained at $0.3 \mathrm{~m}$. The system was calibrated according to the ASTM Standard Procedure E 181-82 (1991) [ref. 6] using standard sources traceable to the National Institute of Standards and Technology. The detector efficiency was measured at several gamma energies between 100 and $1600 \mathrm{keV}$, and a polynomial was fitted to the data to determine efficiency at the desired energies. Periodic quality control checks were made to verify the efficiency and energy calibrations. The counting time for each monitor was varied to obtain total accumulated photopeak counts, in most cases between 10,000 and 20,000. The background counts were also accumulated for the same length of time.

Many fission products are produced in ${ }^{237} \mathrm{~Np}$ fission monitors, among which is $140 \mathrm{Ba}$, having a half-life of $12.75 \mathrm{~d}$. Barium-140 emits gamma rays of several energies; however, these are not easily detected in the presence of other fission products. Barium140 activity was, therefore, indirectly determined by counting gamma rays from its daughter product, ${ }^{140} \mathrm{La}$, several days after irradiation.

\subsection{HELIUM MEASUREMENTS ON HAFMs}

The HAFMs were analyzed at Rockwell International. Each piece of the HAFMs $\mathrm{Li}, \mathrm{Be}$, and B was carefully weighed and placed in a small, tungsten wire, electrical 
Table 3. Activation and fission monitors product nuclide data

\begin{tabular}{|c|c|c|l|}
\hline & & \multicolumn{2}{|c|}{ Gamma ray used } \\
\cline { 3 - 4 } Reaction & Half-life & E $\gamma(\mathrm{keV})$ & $\begin{array}{c}\text { Decay } \\
\text { fraction }\end{array}$ \\
\hline${ }^{27} \mathrm{Al}(\mathrm{n}, \alpha)^{24} \mathrm{Na}$ & $15.03 \mathrm{~h}$ & 1368.6 & 1.0 \\
${ }^{46} \mathrm{Ti}(\mathrm{n}, \mathrm{p}){ }^{46} \mathrm{Sc}$ & $83.8 \mathrm{~d}$ & 889.3 & 1.0 \\
${ }^{54} \mathrm{Fe}(\mathrm{n}, \mathrm{p}){ }^{54} \mathrm{Mn}$ & $312.2 \mathrm{~d}$ & 835.0 & 1.0 \\
${ }^{58} \mathrm{Ni}(\mathrm{n}, \mathrm{p}){ }^{58} \mathrm{Co}$ & $70.78 \mathrm{~d}$ & 811.0 & 0.9944 \\
${ }^{63} \mathrm{Cu}(\mathrm{n}, \alpha){ }^{60} \mathrm{Co}$ & $5.272 \mathrm{y}$ & 1173.2 & 1.0 \\
${ }^{237} \mathrm{~Np}(\mathrm{n}, \mathrm{f}){ }^{140} \mathrm{Ba}$ & $12.75 \mathrm{~d}$ & 1596.0 & 0.954 \\
${ }^{197} \mathrm{Au}(\mathrm{n}, \gamma){ }^{198} \mathrm{Au}$ & $2.697 \mathrm{~d}$ & 411.8 & 0.986 \\
${ }^{59} \mathrm{Co}(\mathrm{n}, \gamma){ }^{60} \mathrm{Co}$ & $5.272 \mathrm{y}$ & 1173.2 & 1.0 \\
${ }^{109} \mathrm{Ag}(\mathrm{n}, \gamma){ }^{110 \mathrm{~m}} \mathrm{Ag}$ & $252.2 \mathrm{~d}$ & 885.0 & 0.735 \\
\hline
\end{tabular}


resistance heater in a vacuum chamber attached to a mass spectrometer. After achieving a satisfactory vacuum level, the specimen was rapidly evaporated to release the helium, which was then measured in a mass spectrometer. The system was calibrated against a known volume of helium-3 spiked into the system. The measured helium concentrations were expressed as atomic parts per billion (appb). A full description of the helium analysis of the HAFMs is available in a letter report from Rockwell International Corporation, dated May 20, 1992 (RI ref. 92RC00784).

\section{DATA ANALYSIS AND RESULTS}

\subsection{DETERMINATION OF REACTION RATES}

For the activation monitors, the measured gamma counts were converted to the corresponding saturation activities (reaction rates) expressed as disintegrations per second per target isotope, and the activities were corrected for self-shielding, depletion of the target isotope, and burn-in and burn-out of the product nuclide using ASTM Standard Procedures. ${ }^{7-15}$ The self-shielding factors were negligible for these monitors except for $\mathrm{Cu}$ which required a $5 \%$ correction. The burn-up factors for $1 \mathrm{~h}$ irradiation were also insignificant except for the nuclide ${ }^{58} \mathrm{Co}$ from the reaction ${ }^{58} \mathrm{Ni}(\mathrm{n}, \mathrm{p}){ }^{58} \mathrm{Co}$ and ${ }^{198} \mathrm{Au}$ from the reaction ${ }^{197} \mathrm{Au}(\mathrm{n}, \gamma){ }^{198} \mathrm{Au}$. The measured saturation activities for the bare activation monitors from capsules NM-192 to -196 are given in Table 4, while saturation activities for the bare and Cd-covered thermal flux monitors from capsules NM-197 and -200 are given in Table 5. Table 5 also lists the difference of the saturation activities of the bare and $\mathrm{Cd}$-covered monitors and the measured cadmium ratio $(\mathrm{R})$ for each monitor.

When ${ }^{237} \mathrm{~Np}$ is irradiated in a neutron field with a high component of thermal flux, most of the ${ }^{140} \mathrm{Ba}$ activity is produced from fission of ${ }^{238} \mathrm{~Np}$ which is produced by the reaction ${ }^{237} \mathrm{~Np}(\mathrm{n}, \gamma){ }^{238} \mathrm{~Np}$ with thermal neutrons. To minimize this contribution in these irradiations, the fission monitors were enclosed in $0.75-\mathrm{mm}$-thick $\mathrm{Cd}$ filters. Therefore, most of the ${ }^{140} \mathrm{Ba}$ activity induced in these monitors was due to fast neutron fissions in ${ }^{237} \mathrm{~Np}$. There is, however, some contribution from photofissions produced by highenergy gamma rays in the irradiation facility and thermal neutron fission of ${ }^{239} \mathrm{Pu}$, which is present as an impurity. The measured ${ }^{140} \mathrm{La}$ activities were not corrected for these contributions. The measured ${ }^{140} \mathrm{La}$ activities were converted to the corresponding fission rates using the relation: 16 
Table 4. Saturation activities $a$ of the bare activation and helium accumulation monitors and $\mathrm{Cd}$-covered fission monitors

(disintegrations per second per atom of target isotope)

\begin{tabular}{|c|c|c|c|c|c|}
\hline Reaction & HT-1 & HT-3 & HT-5 & HT-7 & HT-9 \\
\hline${ }^{27} \mathrm{Al}(\mathrm{n}, \alpha)^{24} \mathrm{Na}$ & $1.45 \times 10^{-13}$ & $3.73 \times 10^{-13}$ & $4.28 \times 10^{-13}$ & $3.74 \times 10^{-13}$ & $1.73 \times 10^{-13}$ \\
${ }^{46} \mathrm{Ti}(\mathrm{n}, \mathrm{p})^{46} \mathrm{Sc}$ & $2.15 \times 10^{-12}$ & $5.94 \times 10^{-12}$ & $6.61 \times 10^{-12}$ & $5.83 \times 10^{-12}$ & $2.50 \times 10^{-12}$ \\
${ }^{54} \mathrm{Fe}(\mathrm{n}, \mathrm{p})^{54} \mathrm{Mn}$ & $1.62 \times 10^{-11}$ & $4.44 \times 10^{-11}$ & $4.96 \times 10^{-11}$ & $4.29 \times 10^{-11}$ & $1.84 \times 10^{-11}$ \\
${ }^{58} \mathrm{Ni}(\mathrm{n}, \mathrm{p})^{58} \mathrm{Co}$ & $2.02 \times 10^{-11}$ & $4.78 \times 10^{-11}$ & $5.55 \times 10^{-11}$ & $4.89 \times 10^{-11}$ & $2.19 \times 10^{-11}$ \\
${ }^{63} \mathrm{Cu}(\mathrm{n}, \alpha)^{60} \mathrm{Co}$ & $1.33 \times 10^{-13}$ & $2.93 \times 10^{-13}$ & $3.35 \times 10^{-13}$ & $2.84 \times 10^{-13}$ & $1.26 \times 10^{-13}$ \\
${ }^{237} \mathrm{~Np}(\mathrm{n}, \mathrm{f})^{140} \mathrm{Ba}{ }^{b}$ & $5.04 \times 10^{-10}$ & - & $1.04 \times 10^{-9}$ & - & - \\
${ }^{9} \mathrm{Be}(\mathrm{n}, \mathrm{He})^{c}$ & $4.69 \times 10^{-11}$ & $1.60 \times 10^{-10}$ & $1.77 \times 10^{-10}$ & - & - \\
${ }^{197} \mathrm{Au}(\mathrm{n}, \gamma){ }^{198} \mathrm{Au}$ & $1.25 \times 10^{-7}$ & $2.78 \times 10^{-7}$ & $2.77 \times 10^{-7}$ & $2.84 \times 10^{-7}$ & $1.48 \times 10^{-7}$ \\
${ }^{59} \mathrm{Co}(\mathrm{n}, \gamma)^{60} \mathrm{Co}$ & $3.27 \times 10^{-8}$ & $5.89 \times 10^{-8}$ & $6.63 \times 10^{-8}$ & $5.69 \times 10^{-8}$ & $3.11 \times 10^{-8}$ \\
${ }^{109} \mathrm{Ag}(\mathrm{n}, \gamma)^{110 \mathrm{~m}} \mathrm{Ag}$ & $5.75 \times 10^{-9}$ & $1.26 \times 10^{-8}$ & $1.41 \times 10^{-8}$ & $1.21 \times 10^{-8}$ & $5.91 \times 10^{-9}$ \\
${ }^{6} \mathrm{Li}(\mathrm{n}, \mathrm{He})^{c}$ & $8.69 \times 10^{-7}$ & $1.67 \times 10^{-6}$ & $1.83 \times 10^{-6}$ & $1.55 \times 10^{-6}$ & $8.45 \times 10^{-7}$ \\
${ }^{10} \mathrm{~B}(\mathrm{n}, \mathrm{He}){ }^{c}$ & $3.74 \times 10^{-6}$ & $7.01 \times 10^{-6}$ & $7.77 \times 10^{-6}$ & $6.54 \times 10^{-6}$ & $3.70 \times 10^{-6}$ \\
\hline
\end{tabular}

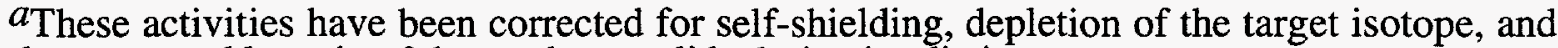
burn-out and burn-in of the product nuclide during irradiation.

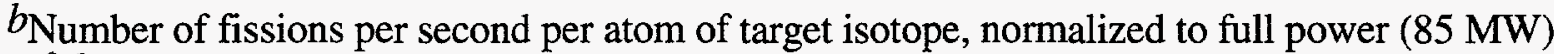
of the reactor.

CNumber of He atoms produced per second per atom of target isotope. 
Table 5. Saturation activities $a$ of the bare and $\mathrm{Cd}$-covered thermal flux monitors

(disintegrations per second per atom of target isotope)

\begin{tabular}{|c|c|c|c|c|}
\hline \multirow{2}{*}{ Location } & & \multicolumn{3}{|c|}{ Monitor } \\
\cline { 3 - 5 } & & $\mathrm{Au}$ & $\mathrm{Ag}$ & $\mathrm{Co}$ \\
\hline \multirow{4}{*}{ HT-1 } & Bare & $1.18 \times 10^{-7}$ & $5.92 \times 10^{-9}$ & $3.18 \times 10^{-8}$ \\
& $\mathrm{Cd}$ & $3.49 \times 10^{-8}$ & $1.68 \times 10^{-9}$ & $1.35 \times 10^{-9}$ \\
& Bare-Cd & $8.31 \times 10^{-8}$ & $4.24 \times 10^{-9}$ & $3.05 \times 10^{-8}$ \\
& $\mathrm{R}$ & 3.38 & 3.52 & 23.56 \\
\hline \multirow{4}{*}{ HT-5 } & Bare & $3.08 \times 10^{-7}$ & $1.50 \times 10^{-8}$ & $6.94 \times 10^{-8}$ \\
& $\mathrm{Cd}$ & $8.79 \times 10^{-8}$ & $4.88 \times 10^{-9}$ & $4.58 \times 10^{-9}$ \\
& Bare-Cd & $2.20 \times 10^{-7}$ & $1.01 \times 10^{-8}$ & $6.48 \times 10^{-8}$ \\
& $\mathrm{R}$ & 3.50 & 3.07 & 15.15 \\
\hline
\end{tabular}

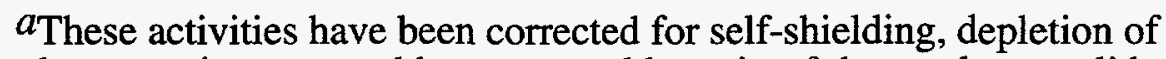
the target isotope, and burn-out and burn-in of the product nuclide during irradiation.

Notes: Activities have been normalized to full power ( $85 \mathrm{MW})$.

$\mathrm{R}$ is Cadmium ratio. $\mathrm{R}$ values for other HT locations were obtained by interpolation and assuming symmetry around HT-5. 


$$
\text { Fissions/second/target isotope }=\frac{\mathrm{A}\left(\lambda_{2}-\lambda_{1}\right)}{\mathrm{N} \lambda_{2} \mathrm{Y}_{1}\left(\mathrm{e}^{-\lambda_{1} \mathrm{t}_{1}}-\mathrm{e}^{-\lambda_{2} \mathrm{t}_{1}}\right) \lambda_{1} \mathrm{t}_{\mathrm{i}}},
$$

where

$\mathrm{A}=140 \mathrm{La}$ activity at the time of measurement (dps),

$\lambda_{1}=$ decay constant for ${ }^{140} \mathrm{Ba}=6.29 \times 10^{-7} \mathrm{~s}^{-1}$,

$\lambda_{2}=$ decay constant for ${ }^{140} \mathrm{La}=4.78 \times 10^{-6} \mathrm{~s}^{-1}$,

$\mathrm{N}=$ number of $237 \mathrm{~Np}$ atoms in the monitor,

$\mathrm{Y}_{1}=$ fission yield of ${ }^{140} \mathrm{Ba}=0.05489$,

$\mathrm{t}_{1}=$ elapsed time between time of counting and irradiation(s),

$\mathrm{t}_{\mathrm{i}}=$ irradiation time(s).

The calculated fission rates are given in Table 4.

The measured helium concentrations (appb) in HAFMs were also converted to helium production rates expressed as the number of $\mathrm{He}$ atoms produced per second per target isotope. They are listed in Table 4.

\subsection{THERMAL FLUX CALCULATIONS}

The true thermal flux, assuming a Maxwellian distribution, was calculated using the relation: 9

$$
\phi_{\mathrm{th}}=\left(\frac{\mathrm{A}_{b}}{\mathrm{G}_{\mathrm{th}} \mathrm{g} \sigma_{0}}\right)\left(\frac{R-1}{R}\right)\left(\sqrt{\frac{4 \mathrm{~T}}{\pi \mathrm{T}_{0}}}\right) \text {, }
$$

where

$$
\begin{aligned}
\phi_{\mathrm{th}} & =\text { true thermal flux }\left(\mathrm{n} / \mathrm{m}^{2} . \mathrm{s}\right) \\
\mathrm{A}_{\mathrm{b}} & =\text { saturation activity of bare monitor }(\mathrm{dps}) \\
\mathrm{G}_{\mathrm{th}} & =\text { thermal self-shielding factor, } \\
\mathrm{g} & =\text { non } 1 / \mathrm{v} \text { factor in the thermal region, } \\
\sigma_{0} & =\text { thermal neutron activation cross section }\left(\mathrm{m}^{2}\right) \\
\mathrm{R} & =\text { cadmium ratio, } \\
\mathrm{T}_{0} & =293.6 \mathrm{~K} \\
\mathrm{~T} & \left.=333.6 \mathrm{~K} \text { (the temperature in the hydraulic tube is close to } 60^{\circ} \mathrm{C}\right)
\end{aligned}
$$


This relation was used to calculate thermal neutron flux using the saturation activities of the bare $\mathrm{Au}, \mathrm{Ag}$, and Co monitors given in Tables 4 and 5 along with the cadmium ratios for these monitors. Since cadmium-covered monitors were irradiated in HT locations 1 and 5 only, the cadmium ratios for the monitors at position 3 were obtained though interpolation, and those for positions 7 and 9 were obtained assuming symmetry around position 5, i.e., $R$ values for positions 7 and 9 were assumed to be the same as for positions 3 and 1 , respectively. The $\mathrm{G}_{\mathrm{th}}, \mathrm{g}$, and $\sigma_{0}$ values for these monitors are given in Table 6 . The calculated thermal flux values are given in Sect. 3.3.

Table 6. Parameters used in thermal flux calculations 9

\begin{tabular}{|c|llc|}
\hline & $\mathrm{Au}$ & $\mathrm{Ag}$ & $\mathrm{Co}$ \\
\hline $\mathrm{G}_{\mathrm{th}}$ & 1.00 & 0.99 & 0.99 \\
$\mathrm{~g}$ & 1.0052 & 1.0062 & 1.00 \\
$\sigma_{0}$ (barns) & 98.8 & 4.1 & 37.45 \\
\hline
\end{tabular}

The thermal neutron flux values at the five HT locations under investigation were also obtained from helium accumulation monitors ${ }^{6} \mathrm{Li}$ and ${ }^{10} \mathrm{~B}$ by dividing the measured helium production rates by the thermal neutron cross sections of 942 barns and 3838 barns for the reactions ${ }^{6} \mathrm{Li}(\mathrm{n}, \alpha){ }^{3} \mathrm{H}$ and ${ }^{10} \mathrm{~B}(\mathrm{n}, \alpha){ }^{7} \mathrm{Li}$, respectively. ${ }^{5}$ The results were corrected for the irradiation temperature using the square root term in Eq. (2). The thermal flux values obtained from these monitors are also given in Sect. 3.3.

\subsection{TOTAL AND FAST FLUX CALCULATIONS}

The first step in the evaluation of total and fast fluxes from the measured reaction rates was to calculate the spectral-averaged cross sections for the reactions of interest. Therefore, one-neutron-energy-group dosimetry cross sections were produced over selected energy ranges for the monitors used in the measurements. The HFIR twodimensional (2-D) geometry model ${ }^{17}$ was modified to include the aluminum tube bundle in the target region. The 64-group neutron cross sections used in radiation transport calculations were produced from the 99-group Advanced Neutron Source Library. 18

The neutron flux was calculated with the DORT, ${ }^{19}$ a 2-D discrete ordinates radiation transport code, using the 64 -group cross sections. The total volume-integrated 
the cross sections. The calculated target region volume-integrated spectrum normalized to one fission neutron is given in Table 7 and is plotted in Fig. 3. With the CRES code, 20 the flux was expanded (using flat weighting) from the 64-group structure to the DOSDAM84 (ref. 21) 640neutron group structure and folded with the predetermined DOSDAM84 dosimetry cross sections. The results were then averaged over the specific energy ranges and reduced to a one-neutron group. The computed cross sections are given in Table 8. The measured reaction rates were divided by the corresponding calculated cross sections to obtain the total and fast fluxes.

In order to evaluate total flux from bare monitor activities, the reaction cross sections were averaged over the entire neutron energy spectrum:

$$
\bar{\sigma}_{\text {Tout }}=\frac{\int_{0}^{\infty} \sigma(\mathrm{E}) \phi(\mathrm{E}) \mathrm{dE}}{\int_{0}^{\infty} \sigma(\mathrm{E}) \mathrm{dE}}
$$

The lower limit in the integrals was set at $10^{-4} \mathrm{eV}$ and the upper limit at $20 \mathrm{MeV}$. The calculated average cross sections, along with the measured activities of the bare monitors, were used to determine total flux from each of the monitors.

The definition of spectral-averaged cross section was modified to:

$$
\bar{\sigma}_{>\mathrm{E}_{0}}=\frac{\int_{0}^{\infty} \sigma(\mathrm{E}) \phi(\mathrm{E}) \mathrm{dE}}{\int_{\mathrm{E}_{0}}^{\infty} \phi(\mathrm{E}) \mathrm{dE}}
$$

to determine fast flux above neutron energy $\mathrm{E}_{0}$, which was set at 0.1 and $1 \mathrm{MeV}$ for the corresponding fluxes from activities of the bare fast flux monitors.

Since the activities induced in the cadmium-covered $\mathrm{Au}, \mathrm{Ag}$, and Co monitors are due to epi-cadmium neutrons only, the epi-cadmium ( $>0.5 \mathrm{eV}$ ) flux values were determined from the activities of these monitors in combination with the average cross sections calculated by setting lower and upper limits of both integrals at $0.5 \mathrm{eV}$ and $20 \mathrm{MeV}$, respectively. The sub-cadmium (< $0.5 \mathrm{eV}$ ) flux values were determined from differences of the activities of the bare and cadmiumcovered monitors along with the average cross sections evaluated in the sub-cadmium range, i.e., with lower and upper limits of both integrals set at $10^{-4}$ and $0.5 \mathrm{eV}$, respectively. 
Table 7. Sixty-four group HFIR aluminum target region total volume-integrated neutron spectrum normalized to one fission neutron

\begin{tabular}{|c|c|c|c|c|c|}
\hline Group & Top E (MeV) & Spectrum $(\mathrm{n} \cdot \mathrm{cm} / \mathrm{s})$ & Group & Top E (MeV) & Spectrum $(\mathrm{n} \cdot \mathrm{cm} / \mathrm{s})$ \\
\hline 1 & $2.0000 \mathrm{E}+01$ & $7.53581 \mathrm{E}-05$ & 33 & $2.2974 \mathrm{E}-01$ & $5.13317 \mathrm{E}-01$ \\
\hline 2 & $1.5941 \mathrm{E}+01$ & $1.01616 \mathrm{E}-03$ & 34 & $1.7411 \mathrm{E}-01$ & 4.47747E-01 \\
\hline 3 & $1.2706 \mathrm{E}+01$ & $7.57756 \mathrm{E}-03$ & 35 & $1.3195 \mathrm{E}-01$ & $4.30975 \mathrm{E}-01$ \\
\hline 4 & $1.0127 \mathrm{E}+01$ & 3.43697E-02 & 36 & $1.0000 \mathrm{E}-01$ & $9.21835 \mathrm{E}-01$ \\
\hline 5 & $8.0722 E+00$ & $1.04587 \mathrm{E}-01$ & 37 & $4.9224 \mathrm{E}-02$ & $7.96638 \mathrm{E}-01$ \\
\hline 6 & $6.4340 \mathrm{E}+00$ & $1.41115 \mathrm{E}-01$ & 38 & $2.4230 \mathrm{E}-02$ & 7.30532E-01 \\
\hline 7 & $5.5234 \mathrm{E}+00$ & $2.20078 \mathrm{E}-01$ & 39 & $1.2017 \mathrm{E}-02$ & $6.90887 \mathrm{E}-01$ \\
\hline 8 & $4.7417 \mathrm{E}+00$ & $3.02087 \mathrm{E}-01$ & 40 & $6.0042 \mathrm{E}-03$ & $6.76460 \mathrm{E}-01$ \\
\hline 9 & $4.0707 \mathrm{E}+00$ & $3.67954 \mathrm{E}-01$ & 41 & $3.0000 \mathrm{E}-03$ & $6.54129 \mathrm{E}-01$ \\
\hline 10 & $3.4946 \mathrm{E}+00$ & 4.71502E-01 & 42 & $1.5220 \mathrm{E}-03$ & $6.49369 \mathrm{E}-01$ \\
\hline 11 & $3.0000 \mathrm{E}+00$ & $3.46830 \mathrm{E}-01$ & 43 & $7.7217 \mathrm{E}-04$ & $6.46214 \mathrm{E}-01$ \\
\hline 12 & $2.7235 E+00$ & $3.82847 \mathrm{E}-01$ & 44 & $3.9110 \mathrm{E}-04$ & $6.42848 \mathrm{E}-01$ \\
\hline 13 & $2.4725 \mathrm{E}+00$ & $4.19737 \mathrm{E}-01$ & 45 & $1.9776 \mathrm{E}-04$ & $6.37196 \mathrm{E}-01$ \\
\hline 14 & $2.2447 \mathrm{E}+00$ & $3.92363 E-01$ & 46 & $1.0000 \mathrm{E}-04$ & $4.45887 \mathrm{E}-01$ \\
\hline 15 & $2.0378 \mathrm{E}+00$ & 3.98497E-01 & 47 & $6.1780 \mathrm{E}-05$ & $4.37630 \mathrm{E}-01$ \\
\hline 16 & $1.8500 \mathrm{E}+00$ & $2.50196 \mathrm{E}-01$ & 48 & $3.8168 \mathrm{E}-05$ & 4.12505E-01 \\
\hline 17 & $1.7497 \mathrm{E}+00$ & $2.42818 \mathrm{E}-01$ & 49 & $2.4082 \mathrm{E}-05$ & $3.86961 \mathrm{E}-01$ \\
\hline 18 & $1.6548 \mathrm{E}+00$ & $2.40055 \mathrm{E}-01$ & 50 & $1.5518 \mathrm{E}-05$ & $3.83647 \mathrm{E}-01$ \\
\hline 19 & $1.5651 \mathrm{E}+00$ & $2.41739 \mathrm{E}-01$ & 51 & $1.0000 \mathrm{E}-05$ & $4.11880 \mathrm{E}-01$ \\
\hline 20 & $1.4803 E+00$ & $2.41814 \mathrm{E}-01$ & 52 & $6.1780 \mathrm{E}-06$ & $6.21981 \mathrm{E}-01$ \\
\hline 21 & $1.4000 E+00$ & $3.71844 \mathrm{E}-01$ & 53 & $3.0000 \mathrm{E}-06$ & $4.73766 \mathrm{E}-01$ \\
\hline 22 & $1.2816 \mathrm{E}+00$ & $3.68101 \mathrm{E}-01$ & 54 & $1.7700 \mathrm{E}-06$ & $1.41791 \mathrm{E}-01$ \\
\hline 23 & $1.1732 \mathrm{E}+00$ & $3.51047 \mathrm{E}-01$ & 55 & $3.9700 \mathrm{E}-07$ & $1.87787 \mathrm{E}-01$ \\
\hline 24 & $1.0740 \mathrm{E}+00$ & $3.10802 \mathrm{E}-01$ & 56 & $3.3000 \mathrm{E}-07$ & $2.19794 E-01$ \\
\hline 25 & $9.8315 \mathrm{E}-01$ & $3.20109 \mathrm{E}-01$ & 57 & $2.7000 \mathrm{E}-07$ & 3.22537E-01 \\
\hline 26 & $9.0000 \mathrm{E}-01$ & $6.20893 \mathrm{E}-01$ & 58 & $2.1500 \mathrm{E}-07$ & $6.90217 \mathrm{E}-01$ \\
\hline 27 & $7.6525 \mathrm{E}-01$ & $6.02982 \mathrm{E}-01$ & 59 & $1.6200 \mathrm{E}-07$ & $2.55123 \mathrm{E}+00$ \\
\hline 28 & $6.5068 \mathrm{E}-01$ & $5.14038 \mathrm{E}-01$ & 60 & $1.0400 \mathrm{E}-07$ & $8.85592 \mathrm{E}+00$ \\
\hline 29 & $5.5326 \mathrm{E}-01$ & $4.75971 \mathrm{E}-01$ & 61 & $5.0000 \mathrm{E}-08$ & $6.16908 \mathrm{E}+00$ \\
\hline 30 & 4.7043E-01 & $3.72404 \mathrm{E}-01$ & 62 & $3.0000 \mathrm{E}-08$ & $6.12899 \mathrm{E}+00$ \\
\hline 31 & $4.0000 \mathrm{E}-01$ & $6.91834 \mathrm{E}-01$ & 63 & $1.0000 \mathrm{E}-08$ & $9.75097 \mathrm{E}-01$ \\
\hline 32 & $3.0314 \mathrm{E}-01$ & $6.09022 \mathrm{E}-01$ & 64 & $\begin{array}{l}4.4500 \mathrm{E}-09 \\
1.0000 \mathrm{E}-10\end{array}$ & $2.60110 \mathrm{E} \sim 01$ \\
\hline
\end{tabular}


Target Region Volume-Integrated Spectrum (n-cm/s-eV)

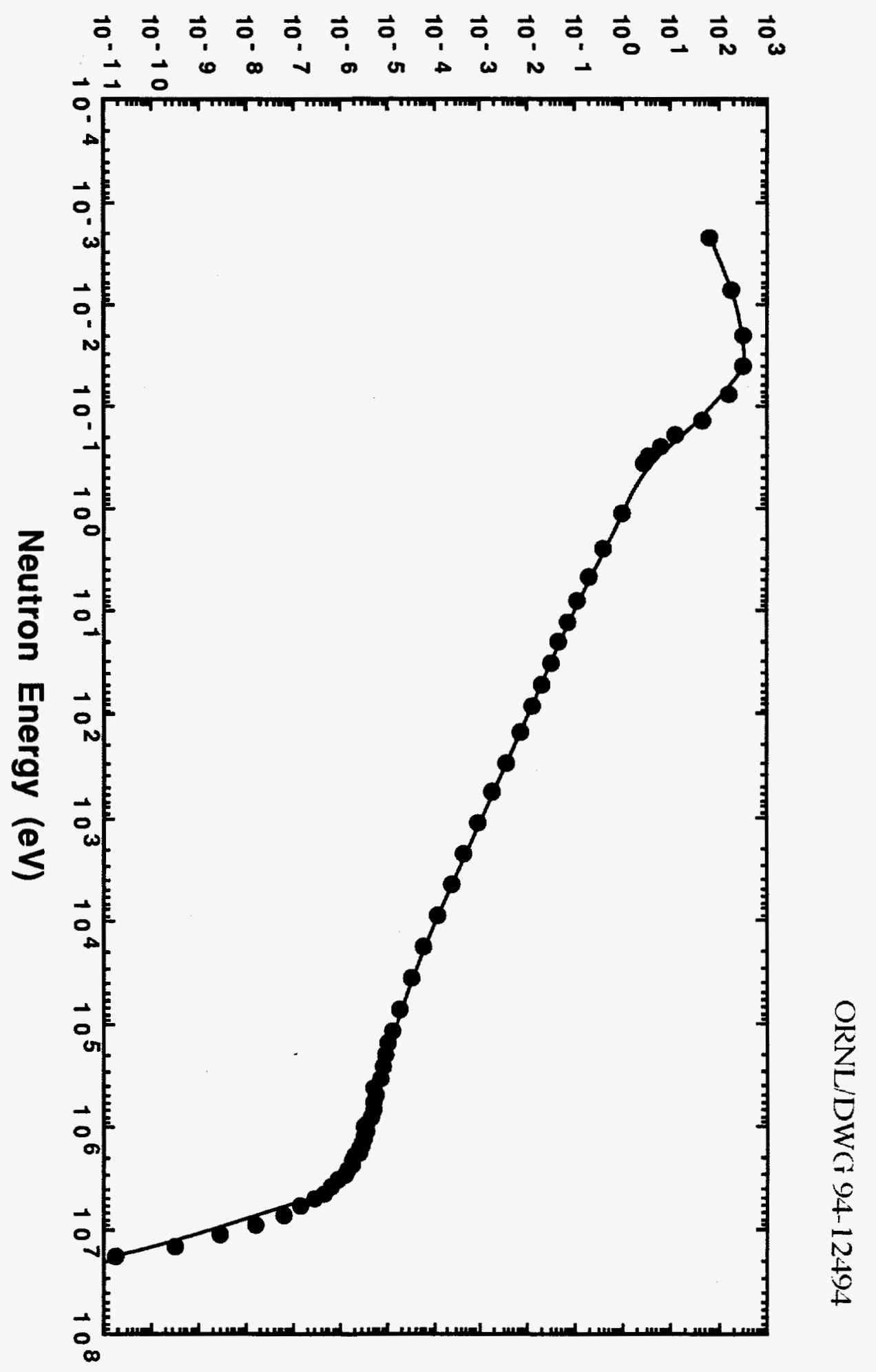


Table 8. One-group volume-integrated beginning-of-cycle cross sections (reaction or production) averaged over spectrum in the HFIR target region ( $\mathrm{m}^{2} /$ neutron $\cdot$ atom)

\begin{tabular}{|c|c|c|c|c|c|c|c|}
\hline Reaction & $\begin{array}{l}\mathrm{E} 1=1 \times 10^{-4} \mathrm{eV} \\
\mathrm{E} 2=20.0 \mathrm{MeV} \\
\mathrm{E} 3=1 \times 10^{-4} \mathrm{eV} \\
\mathrm{E} 4=20.0 \mathrm{MeV}\end{array}$ & $\begin{array}{l}\mathrm{E} 1=1 \times 10^{-4} \mathrm{eV} \\
\mathrm{E} 2=20.0 \mathrm{MeV} \\
\mathrm{E} 3=1.0 \mathrm{MeV} \\
\mathrm{E} 4=20.0 \mathrm{MeV}\end{array}$ & $\begin{array}{l}\mathrm{E} 1=1 \times 10^{-4} \mathrm{eV} \\
\mathrm{E} 2=20.0 \mathrm{MeV} \\
\mathrm{E} 3=0.1 \mathrm{MeV} \\
\mathrm{E} 4=20.0 \mathrm{MeV}\end{array}$ & $\begin{array}{l}\mathrm{E} 1=1 \times 10^{-4} \mathrm{eV} \\
\mathrm{E} 2=20.0 \mathrm{MeV} \\
\mathrm{E} 3=0.5 \mathrm{eV} \\
\mathrm{E} 4=20.0 \mathrm{MeV}\end{array}$ & $\begin{array}{l}\mathrm{E} 1=1 \times 10^{-4} \mathrm{eV} \\
\mathrm{E} 2=20.0 \mathrm{MeV} \\
\mathrm{E} 3=1 \times 10^{-4} \mathrm{eV} \\
\mathrm{E} 4=0.5 \mathrm{eV}\end{array}$ & $\begin{array}{l}\mathrm{E} 1=0.5 \mathrm{eV} \\
\mathrm{E} 2=20.0 \mathrm{MeV} \\
\mathrm{E} 3=0.5 \mathrm{eV} \\
\mathrm{E} 4=20.0 \mathrm{MeV}\end{array}$ & $\begin{array}{l}\mathrm{E} 1=1 \times 10^{-4} \mathrm{eV} \\
\mathrm{E} 2=0.5 \mathrm{eV} \\
\mathrm{E} 3=1 \times 10^{-4} \mathrm{eV} \\
\mathrm{E} 4=0.5 \mathrm{eV}\end{array}$ \\
\hline${ }^{9} \mathrm{Be}(\mathrm{n}, \mathrm{He}$ Prod $)$ & $4.3284 \times 10^{-30}$ & $3.5328 \times 10^{-29}$ & $1.8404 \times 10^{-29}$ & $9.1540 \times 10^{-30}$ & 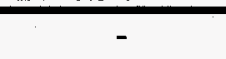 & - & - \\
\hline${ }^{6} \mathrm{Li}(\mathrm{n}, \mathrm{He}$ Prod) & $4.1424 \times 10^{-26}$ & $3.3810 \times 10^{-25}$ & $1.7613 \times 10^{-25}$ & - & $7.8581 \times 10^{-26}$ & - & - \\
\hline${ }^{10} \mathrm{~B}$ (n, He Prod) & $1.6972 \times 10^{-25}$ & $1.3852 \times 10^{-24}$ & $7.2163 \times 10^{-25}$ & - & $3.2196 \times 10^{-25}$ & - & - \\
\hline${ }^{11} \mathrm{~B}(\mathrm{n}, \mathrm{He}$ Prod) & $7.0046 \times 10^{-34}$ & $5.7171 \times 10^{-33}$ & $2.9783 \times 10^{-33}$ & - & - & - & - \\
\hline${ }^{27} \mathrm{Al}(\mathrm{n}, \alpha){ }^{24} \mathrm{Na}$ & $1.2055 \times 10^{-32}$ & $9.8393 \times 10^{-32}$ & $5.1256 \times 10^{-32}$ & $2.5459 \times 10^{-32}$ & - & - & - \\
\hline${ }^{45} \mathrm{Sc}(\mathrm{n}, \gamma)^{46} \mathrm{Sc}$ & $1.2017 \times 10^{-27}$ & $9.8082 \times 10^{-27}$ & $5.1095 \times 10^{-27}$ & - & - & $4.7011 \times 10^{-29}$ & $2.2374 \times 10^{-27}$ \\
\hline${ }^{46} \mathrm{Ti}(\mathrm{n}, \mathrm{p}){ }^{46} \mathrm{Sc}$ & $1.7182 \times 10^{-31}$ & $1.4024 \times 10^{-30}$ & $7.3055 \times 10^{-31}$ & $3.6338 \times 10^{-31}$ & - & - & - \\
\hline${ }^{54} \mathrm{Fe}(\mathrm{n}, \mathrm{p})^{54} \mathrm{Mn}$ & $1.2548 \times 10^{-30}$ & $1.0242 \times 10^{-29}$ & $5.3352 \times 10^{-30}$ & $2.6537 \times 10^{-30}$ & - & - & - \\
\hline${ }^{58} \mathrm{Fe}(\mathrm{n}, \gamma)^{59} \mathrm{Fe}$ & $5.2567 \times 10^{-29}$ & $4.2905 \times 10^{-28}$ & $2.2351 \times 10^{-28}$ & - & - & $5.5519 \times 10^{-30}$ & $9.4739 \times 10^{-29}$ \\
\hline${ }^{58} \mathrm{Ni}(\mathrm{n}, \mathrm{p})^{58} \mathrm{Co}$ & $1.6447 \times 10^{-30}$ & $1.3424 \times 10^{-29}$ & $6.9930 \times 10^{-30}$ & $3.4783 \times 10^{-30}$ & - & 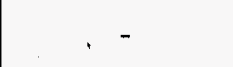 & \\
\hline${ }^{59} \mathrm{Co}(\mathrm{n}, \gamma){ }^{60} \mathrm{Co}$ & $1.7442 \times 10^{-27}$ & $1.4236 \times 10^{-26}$ & $7.4161 \times 10^{-27}$ & $3.6887 \times 10^{-27}$ & - & $2.6941 \times 10^{-28}$ & $3.0670 \times 10^{-27}$ \\
\hline${ }^{63} \mathrm{Cu}(\mathrm{n}, \alpha){ }^{60} \mathrm{Co}$ & $8.9234 \times 10^{-33}$ & $7.2833 \times 10^{-32}$ & $3.7941 \times 10^{-32}$ & $1.8872 \times 10^{-32}$ & - & - & - \\
\hline${ }^{109} \mathrm{Ag}(\mathrm{n}, \gamma){ }^{110 \mathrm{~m}} \mathrm{Ag}$ & $3.6666 \times 10^{-28}$ & $2.9927 \times 10^{-27}$ & $1.5590 \times 10^{-27}$ & $7.7543 \times 10^{-28}$ & - & $3.2529 \times 10^{-28}$ & $4.0377 \times 10^{-28}$ \\
\hline${ }^{139} \mathrm{La}(\mathrm{n}, \gamma)^{140} \mathrm{La}$ & $4.1110 \times 10^{-28}$ & $3.3554 \times 10^{-27}$ & $1.7479 \times 10^{-27}$ & - & - & - & - \\
\hline${ }^{197} \mathrm{Au}(\mathrm{n}, \gamma){ }^{198} \mathrm{Au}$ & $7.2895 \times 10^{-27}$ & $5.9497 \times 10^{-26}$ & $3.0994 \times 10^{-26}$ & $1.5416 \times 10^{-26}$ & - & $6.2806 \times 10^{-27}$ & $8.1944 \times 10^{-27}$ \\
\hline${ }^{237} \mathrm{~Np}(\mathrm{n}, \mathrm{f})$ & $2.7159 \times 10^{-29}$ & $2.2167 \times 10^{-28}$ & $1.1548 \times 10^{-28}$ & $5.7437 \times 10^{-29}$ & - & - & - \\
\hline${ }^{237} \mathrm{~Np}(\mathrm{n}, \gamma)^{238} \mathrm{~Np}$ & $8.5182 \times 10^{-27}$ & $6.9525 \times 10^{-26}$ & $3.6218 \times 10^{-26}$ & - & - & - & - \\
\hline
\end{tabular}

Note: Average one-group cross section, $\bar{\sigma}=\frac{\left.\int_{\mathrm{El}}^{\mathrm{E}} \sigma \mathrm{E}\right) \phi(\mathrm{E}) \mathrm{dE}}{\int_{\mathrm{E}}^{\mathrm{g}} \phi(\mathrm{E}) \mathrm{dE}}$, for the integral limits given at the heads of the columns. 
The measured total, thermal, fast ( $\mathrm{E}>0.1 \mathrm{MeV}$ and $>1 \mathrm{MeV}$ ), epi-cadmium, and subcadmium fluxes are given in Tables 9-13. The average values of these fluxes and some important flux ratios are given in Tables 14 and 15, respectively, and are plotted as a function of HT location in Figs. 4 and 5, respectively.

\section{DISCUSSION AND CONCLUSIONS}

The purpose of this dosimetry experiment was to measure the neutron flux spectrum along the length of the HFIR hydraulic tube. Out of the nine rabbit capsule positions (HT-1 though -9) in the hydraulic tube, the flux was measured at the five odd-numbered positions using activation, fission, and HAFMs. This measured flux spectrum provides necessary information to analyze the results of the hydraulic tube irradiations that have already been performed and to design future irradiations.

Due to a high thermal neutron component of flux in the hydraulic tube, attempts were made to minimize some undesirable effects of the thermal flux and/or to correct the measurements for these effects that include burn-in and/or burn-out of the product nuclide, self-shielding, depletion of the target isotope, and interference from impurities. Burn-up of the product nuclide in most of the reactions given in Table 1 was negligible except for the nuclides ${ }^{58} \mathrm{Co}$ from the reaction $58 \mathrm{Ni}$ (n,p) ${ }^{58} \mathrm{Co}$ and ${ }^{198} \mathrm{Au}$ from the reaction ${ }^{197} \mathrm{Au}(\mathrm{n}, \gamma){ }^{198} \mathrm{Au}$. A 1-h irradiation of these monitors in a thermal flux on the order of $10^{19} \mathrm{n} / \mathrm{m}^{2}$.s required more than $20 \%$ correction. The selfshielding factors were also negligible for the monitors used in this experiment, except for $\mathrm{Cu}$ which required a $5 \%$ correction.

When a ${ }^{237} \mathrm{~Np}$ fission monitor is irradiated in a neutron field with a high component of thermal flux, most of the ${ }^{140} \mathrm{Ba}$ activity is produced from the fissioning of $238 \mathrm{~Np}$, which is produced by the reaction ${ }^{237} \mathrm{~Np}(\mathrm{n}, \gamma){ }^{238} \mathrm{~Np}$. In addition, ${ }^{239} \mathrm{Pu}$, which is present as an impurity, also fissions with thermal neutrons and contributes to the ${ }^{140} \mathrm{Ba}$ activity. These contributions in this experiment were minimized by irradiating the fission monitors in $0.75-\mathrm{mm}$ thick $\mathrm{Cd}$ filters. Therefore, most of the ${ }^{140} \mathrm{Ba}$ activity induced in these monitors was due to fast neutron fissions in ${ }^{237} \mathrm{~Np}$. There is, however, always some contribution from ${ }^{238} \mathrm{~Np},{ }^{239} \mathrm{Pu}$, and photofissions produced by high-energy gamma rays in the irradiation facility. The measured $140 \mathrm{La}$ and hence $140 \mathrm{Ba}$ activities were not corrected for these contributions due to uncertainties in the magnitude of these effects.

When a ${ }^{9} \mathrm{Be}$ HAFM is exposed to a fast neutron flux, helium is produced though three separate reactions: ${ }^{9} \mathrm{Be}(\mathrm{n}, \alpha){ }^{6} \mathrm{He}(\alpha+2 \mathrm{n}) ;{ }^{9} \mathrm{Be}(\mathrm{n}, 2 \mathrm{n}){ }^{8} \mathrm{Be}(2 \alpha)$; and ${ }^{9} \mathrm{Be}(\mathrm{n}, \mathrm{d}){ }^{2} \alpha$. 
Table 9. Measured neutron fluxes $\left(\mathrm{n} / \mathrm{m}^{2} \cdot \mathrm{s}\right)$ at HFIR HT-1

\begin{tabular}{|l|c|c|c|c|}
\hline \multicolumn{1}{|c|}{ Reaction } & Total & Thermal & $>0.1 \mathrm{MeV}$ & $>1 \mathrm{MeV}$ \\
\hline${ }^{27} \mathrm{Al}(\mathrm{n}, \alpha)^{24} \mathrm{Na}$ & $1.2 \times 10^{19}$ & & $2.8 \times 10^{18}$ & $1.5 \times 10^{18}$ \\
${ }^{46} \mathrm{Ti}(\mathrm{n}, \mathrm{p})^{46} \mathrm{Sc}$ & $1.3 \times 10^{19}$ & & $2.9 \times 10^{18}$ & $1.5 \times 10^{18}$ \\
${ }^{54} \mathrm{Fe}(\mathrm{n}, \mathrm{p})^{54} \mathrm{Mn}$ & $1.3 \times 10^{19}$ & & $3.0 \times 10^{18}$ & $1.6 \times 10^{18}$ \\
${ }^{58} \mathrm{Ni}(\mathrm{n}, \mathrm{p})^{58} \mathrm{Co}$ & $1.2 \times 10^{19}$ & & $2.9 \times 10^{18}$ & $1.5 \times 10^{18}$ \\
${ }^{63} \mathrm{Cu}(\mathrm{n}, \alpha)^{60} \mathrm{Co}$ & $1.5 \times 10^{19}$ & & $3.5 \times 10^{18}$ & $1.8 \times 10^{18}$ \\
${ }^{237} \mathrm{~Np}(\mathrm{n}, \mathrm{f})$ & $1.9 \times 10^{19}$ & & $4.4 \times 10^{18}$ & $2.3 \times 10^{18}$ \\
${ }^{9} \mathrm{Be}(\mathrm{n}, \mathrm{He})$ & $1.1 \times 10^{19}$ & & $2.6 \times 10^{18}$ & $1.3 \times 10^{18}$ \\
${ }^{197} \mathrm{Au}(\mathrm{n}, \gamma)^{198} \mathrm{Au}$ & $1.7 \times 10^{19}$ & $1.1 \times 10^{19}$ & & \\
${ }^{59} \mathrm{Co}(\mathrm{n}, \gamma)^{60} \mathrm{Co}$ & $1.9 \times 10^{19}$ & $1.0 \times 10^{19}$ & & \\
${ }^{109} \mathrm{Ag}(\mathrm{n}, \gamma)^{110 \mathrm{~m}} \mathrm{Ag}$ & $1.6 \times 10^{19}$ & $1.2 \times 10^{19}$ & & \\
${ }^{6} \mathrm{Li}(\mathrm{n}, \mathrm{He})$ & $2.1 \times 10^{19}$ & $1.1 \times 10^{19}$ & & \\
${ }^{10} \mathrm{~B}(\mathrm{n}, \mathrm{He})$ & $2.2 \times 10^{19}$ & $1.1 \times 10^{19}$ & & \\
\hline & & & $>0.5 \mathrm{eV}$ & $<0.5 \mathrm{eV}$ \\
\hline${ }^{197} \mathrm{Au}(\mathrm{n}, \gamma)^{198} \mathrm{Au}$ & $1.6 \times 10^{19}$ & $1.0 \times 10^{19}$ & $5.6 \times 10^{18}$ & $1.0 \times 10^{19}$ \\
${ }^{109} \mathrm{Ag}(\mathrm{n}, \gamma)^{110 \mathrm{~m}} \mathrm{Ag}(\mathrm{n}, \gamma)^{60} \mathrm{Co}$ & $1.6 \times 10^{19}$ & $1.2 \times 10^{19}$ & $5.2 \times 10^{18}$ & $1.1 \times 10^{19}$ \\
\hline${ }^{59} \times 10^{19}$ & $9.9 \times 10^{18}$ & $5.0 \times 10^{18}$ & $1.2 \times 10^{19}$ \\
\hline
\end{tabular}


Table 10. Measured neutron fluxes $\left(\mathrm{n} / \mathrm{m}^{2} \cdot \mathrm{s}\right)$ at HFIR HT-3

\begin{tabular}{|c|c|c|c|c|}
\hline Reaction & Total & Thermal & $>0.1 \mathrm{MeV}$ & $>1 \mathrm{MeV}$ \\
\hline${ }^{27} \mathrm{Al}(\mathrm{n}, \alpha){ }^{24} \mathrm{Na}$ & $3.1 \times 10^{19}$ & & $7.3 \times 10^{18}$ & $3.8 \times 10^{18}$ \\
\hline${ }^{46} \mathrm{Ti}(\mathrm{n}, \mathrm{p}){ }^{46} \mathrm{Sc}$ & $3.5 \times 10^{19}$ & & $8.1 \times 10^{18}$ & $4.2 \times 10^{18}$ \\
\hline${ }^{54} \mathrm{Fe}(\mathrm{n}, \mathrm{p}){ }^{54} \mathrm{Mn}$ & $3.5 \times 10^{19}$ & & $8.3 \times 10^{18}$ & $4.3 \times 10^{18}$ \\
\hline${ }^{58} \mathrm{Ni}(\mathrm{n}, \mathrm{p}){ }^{58} \mathrm{Co}$ & $2.9 \times 10^{19}$ & & $6.8 \times 10^{18}$ & $3.6 \times 10^{18}$ \\
\hline${ }^{63} \mathrm{Cu}(\mathrm{n}, \alpha){ }^{60} \mathrm{Co}$ & $3.3 \times 10^{19}$ & & $7.7 \times 10^{18}$ & $4.0 \times 10^{18}$ \\
\hline${ }^{237} \mathrm{~Np}(\mathrm{n}, \mathrm{f})$ & & & & \\
\hline${ }^{9} \mathrm{Be}(\mathrm{n}, \mathrm{He})$ & $3.7 \times 10^{19}$ & & $8.7 \times 10^{18}$ & $4.5 \times 10^{18}$ \\
\hline${ }^{197} \mathrm{Au}(\mathrm{n}, \gamma){ }^{198} \mathrm{Au}$ & $3.8 \times 10^{19}$ & $2.4 \times 10^{19}$ & & \\
\hline${ }^{59} \mathrm{Co}(\mathrm{n}, \gamma){ }^{60} \mathrm{Co}$ & $3.4 \times 10^{19}$ & $1.8 \times 10^{19}$ & & \\
\hline${ }^{109} \mathrm{Ag}(\mathrm{n}, \gamma)^{110 \mathrm{~m}} \mathrm{Ag}$ & $3.4 \times 10^{19}$ & $2.6 \times 10^{19}$ & & \\
\hline${ }^{6} \mathrm{Li}(\mathrm{n}, \mathrm{He})$ & $4.0 \times 10^{19}$ & $2.0 \times 10^{19}$ & & \\
\hline${ }^{10} \mathrm{~B}(\mathrm{n}, \mathrm{He})$ & $4.1 \times 10^{19}$ & $2.2 \times 10^{19}$ & & \\
\hline
\end{tabular}


Table 11. Measured neutron fluxes $\left(\mathrm{n} / \mathrm{m}^{2} \cdot \mathrm{s}\right)$ at HFIR HT-5

\begin{tabular}{|l|c|c|c|c|}
\hline Reaction & Total & Thermal & $>0.1 \mathrm{MeV}$ & $>1 \mathrm{MeV}$ \\
\hline${ }^{27} \mathrm{Al}(\mathrm{n}, \alpha)^{24} \mathrm{Na}$ & $3.5 \times 10^{19}$ & & $8.3 \times 10^{18}$ & $4.3 \times 10^{18}$ \\
${ }^{46} \mathrm{Ti}(\mathrm{n}, \mathrm{p})^{46} \mathrm{Sc}$ & $3.8 \times 10^{19}$ & & $9.1 \times 10^{18}$ & $4.7 \times 10^{18}$ \\
${ }^{54} \mathrm{Fe}(\mathrm{n}, \mathrm{p})^{54} \mathrm{Mn}$ & $3.9 \times 10^{19}$ & & $9.3 \times 10^{18}$ & $4.8 \times 10^{18}$ \\
${ }^{58} \mathrm{Ni}(\mathrm{n}, \mathrm{p})^{58} \mathrm{Co}$ & $3.4 \times 10^{19}$ & & $7.9 \times 10^{18}$ & $4.2 \times 10^{18}$ \\
${ }^{63} \mathrm{Cu}(\mathrm{n}, \alpha)^{60} \mathrm{Co}$ & $3.8 \times 10^{19}$ & & $8.8 \times 10^{18}$ & $4.6 \times 10^{18}$ \\
${ }^{237} \mathrm{~Np}(\mathrm{n}, \mathrm{f})$ & $3.8 \times 10^{19}$ & & $9.0 \times 10^{18}$ & $4.7 \times 10^{18}$ \\
${ }^{9} \mathrm{Be}(\mathrm{n}, \mathrm{He})$ & $4.1 \times 10^{19}$ & & $9.6 \times 10^{18}$ & $5.0 \times 10^{18}$ \\
${ }^{197} \mathrm{Au}(\mathrm{n}, \gamma)^{198} \mathrm{Au}$ & $3.8 \times 10^{19}$ & $2.4 \times 10^{19}$ & & \\
${ }^{59} \mathrm{Co}(\mathrm{n}, \gamma)^{60} \mathrm{Co}$ & $3.8 \times 10^{19}$ & $2.2 \times 10^{19}$ & & \\
${ }^{109} \mathrm{Ag}(\mathrm{n}, \gamma)^{110 \mathrm{~m}} \mathrm{Ag}$ & $3.9 \times 10^{19}$ & $2.8 \times 10^{19}$ & & \\
${ }^{6} \mathrm{Li}(\mathrm{n}, \mathrm{He})$ & $4.4 \times 10^{19}$ & $2.3 \times 10^{19}$ & & \\
${ }^{10} \mathrm{~B}(\mathrm{n}, \mathrm{He})$ & $4.6 \times 10^{19}$ & $2.4 \times 10^{19}$ & & \\
\hline${ }^{59} \mathrm{Co}(\mathrm{n}, \gamma)^{60} \mathrm{Co}$ & $4.0 \times 10^{19}$ & $2.3 \times 10^{19}$ & $1.7 \times 10^{19}$ & $2.1 \times 10^{19}$ \\
\hline${ }^{197} \mathrm{Au}(\mathrm{n}, \gamma){ }^{198} \mathrm{Au}$ & $4.3 \times 10^{19}$ & $2.7 \times 10^{19}$ & $1.4 \times 10^{19}$ & $2.7 \times 10^{19}$ \\
${ }^{109} \mathrm{Ag}(\mathrm{n}, \gamma)^{110 \mathrm{~m}} \mathrm{Ag}$ & $4.1 \times 10^{19}$ & $2.9 \times 10^{19}$ & $1.5 \times 10^{19}$ & $2.5 \times 10^{19}$ \\
${ }^{50}$ & & & $>0.5 \mathrm{eV}$ & $<0.5 \mathrm{eV}$ \\
\hline
\end{tabular}


Table 12. Measured neutron fluxes $\left(\mathrm{n} / \mathrm{m}^{2} \cdot \mathrm{s}\right)$ at HFIR HT-7

\begin{tabular}{|c|c|c|c|c|}
\hline Reaction & Total & Thermal & $>0.1 \mathrm{MeV}$ & $>1 \mathrm{MeV}$ \\
\hline${ }^{27} \mathrm{Al}(\mathrm{n}, \alpha){ }^{24} \mathrm{Na}$ & $3.1 \times 10^{19}$ & & $7.3 \times 10^{18}$ & $3.8 \times 10^{18}$ \\
\hline${ }^{46} \mathrm{Ti}(\mathrm{n}, \mathrm{p}){ }^{46} \mathrm{Sc}$ & $3.4 \times 10^{19}$ & & $8.0 \times 10^{18}$ & $4.2 \times 10^{18}$ \\
\hline${ }^{54} \mathrm{Fe}(\mathrm{n}, \mathrm{p}){ }^{54} \mathrm{Mn}$ & $3.4 \times 10^{19}$ & & $8.0 \times 10^{18}$ & $4.2 \times 10^{18}$ \\
\hline${ }^{58} \mathrm{Ni}(\mathrm{n}, \mathrm{p})^{58} \mathrm{Co}$ & $3.0 \times 10^{19}$ & & $7.0 \times 10^{18}$ & $3.7 \times 10^{18}$ \\
\hline${ }^{63} \mathrm{Cu}(\mathrm{n}, \alpha){ }^{60} \mathrm{Co}$ & $3.2 \times 10^{19}$ & & $7.5 \times 10^{18}$ & $3.9 \times 10^{18}$ \\
\hline${ }^{237} \mathrm{~Np}(\mathrm{n}, \mathrm{f})$ & & & & \\
\hline${ }^{9} \mathrm{Be}(\mathrm{n}, \mathrm{He})$ & & & & \\
\hline${ }^{197} \mathrm{Au}(\mathrm{n}, \gamma){ }^{198} \mathrm{Au}$ & $3.9 \times 10^{19}$ & $2.4 \times 10^{19}$ & & \\
\hline${ }^{59} \mathrm{Co}(\mathrm{n}, \gamma){ }^{60} \mathrm{Co}$ & $3.3 \times 10^{19}$ & $1.8 \times 10^{19}$ & & \\
\hline${ }^{109} \mathrm{Ag}(\mathrm{n}, \gamma){ }^{110 \mathrm{~m}} \mathrm{Ag}$ & $3.3 \times 10^{19}$ & $2.5 \times 10^{19}$ & & \\
\hline${ }^{6} \mathrm{Li}(\mathrm{n}, \mathrm{He})$ & $3.7 \times 10^{19}$ & $1.9 \times 10^{19}$ & & \\
\hline${ }^{10} \mathrm{~B}(\mathrm{n}, \mathrm{He})$ & $3.9 \times 10^{19}$ & $2.0 \times 10^{19}$ & & \\
\hline
\end{tabular}


Table 13. Measured neutron fluxes $\left(\mathrm{n} / \mathrm{m}^{2} \cdot \mathrm{s}\right)$ at HFIR HT-9

\begin{tabular}{|l|c|c|c|c|}
\hline \multicolumn{1}{|c|}{ Reaction } & Total & Thermal & $>0.1 \mathrm{MeV}$ & $>1 \mathrm{MeV}$ \\
\hline${ }^{27} \mathrm{Al}(\mathrm{n}, \alpha)^{24} \mathrm{Na}$ & $1.4 \times 10^{19}$ & & $3.4 \times 10^{18}$ & $1.8 \times 10^{18}$ \\
${ }^{46} \mathrm{Ti}(\mathrm{n}, \mathrm{p})^{46} \mathrm{Sc}$ & $1.5 \times 10^{19}$ & & $3.4 \times 10^{18}$ & $1.8 \times 10^{18}$ \\
${ }^{54} \mathrm{Fe}(\mathrm{n}, \mathrm{p})^{54} \mathrm{Mn}$ & $1.5 \times 10^{19}$ & & $3.4 \times 10^{18}$ & $1.8 \times 10^{18}$ \\
${ }^{58} \mathrm{Ni}(\mathrm{n}, \mathrm{p})^{58} \mathrm{Co}$ & $1.3 \times 10^{19}$ & & $3.1 \times 10^{18}$ & $1.6 \times 10^{18}$ \\
${ }^{63} \mathrm{Cu}(\mathrm{n}, \alpha)^{60} \mathrm{Co}$ & $1.4 \times 10^{19}$ & & $3.3 \times 10^{18}$ & $1.7 \times 10^{18}$ \\
${ }^{237} \mathrm{~Np}(\mathrm{n}, \mathrm{f})$ & & & & \\
${ }^{9} \mathrm{Be}(\mathrm{n}, \mathrm{He})$ & & & & \\
${ }^{197} \mathrm{Au}(\mathrm{n}, \gamma)^{198} \mathrm{Au}$ & $2.0 \times 10^{19}$ & $1.3 \times 10^{19}$ & & \\
${ }^{59} \mathrm{Co}(\mathrm{n}, \gamma)^{60} \mathrm{Co}$ & $1.8 \times 10^{19}$ & $9.7 \times 10^{18}$ & & \\
${ }^{109} \mathrm{Ag}(\mathrm{n}, \gamma)^{110 \mathrm{~m}} \mathrm{Ag}$ & $1.6 \times 10^{19}$ & $1.2 \times 10^{19}$ & & \\
${ }^{6} \mathrm{Li}(\mathrm{n}, \mathrm{He})$ & $2.0 \times 10^{19}$ & $1.1 \times 10^{19}$ & \\
${ }^{10} \mathrm{~B}(\mathrm{n}, \mathrm{He})$ & $2.2 \times 10^{19}$ & $1.1 \times 10^{19}$ & & \\
\hline
\end{tabular}


Table 14. Average values of the measured neutron fluxes $\left(n / m^{2} \cdot s\right)$ in the HFIR hydraulic tube

\begin{tabular}{|c|c|c|c|c|c|c|}
\hline HT Location & Total & Thermal & $<0.5 \mathrm{eV}$ & $>0.5 \mathrm{eV}$ & $>0.1 \mathrm{MeV}$ & $>1 \mathrm{MeV}$ \\
\hline HT-1 & $1.6 \times 10^{19}$ & $1.1 \times 10^{19}$ & $1.1 \times 10^{19}$ & $5.3 \times 10^{18}$ & $3.2 \times 10^{18}$ & $1.6 \times 10^{18}$ \\
HT-3 & $3.5 \times 10^{19}$ & $2.2 \times 10^{19}$ & & & $7.8 \times 10^{18}$ & $4.1 \times 10^{18}$ \\
HT-5 & $4.0 \times 10^{19}$ & $2.5 \times 10^{19}$ & $2.4 \times 10^{19}$ & $1.5 \times 10^{19}$ & $8.9 \times 10^{18}$ & $4.6 \times 10^{18}$ \\
HT-7 & $3.4 \times 10^{19}$ & $2.1 \times 10^{19}$ & & & $7.6 \times 10^{18}$ & $4.0 \times 10^{18}$ \\
HT-9 & $1.7 \times 10^{19}$ & $1.1 \times 10^{19}$ & & & $3.3 \times 10^{18}$ & $1.7 \times 10^{18}$ \\
\hline
\end{tabular}

Table 15. Measured flux ratios in the HFIR hydraulic tube

\begin{tabular}{|c|c|c|c|}
\hline Location & $\phi_{\mathrm{th}} / \phi>1 \mathrm{MeV}$ & $\phi_{\mathrm{th}} / \phi>0.1 \mathrm{MeV}$ & $\phi_{>0.1 \mathrm{MeV}} / \phi>1 \mathrm{MeV}$ \\
\hline HT-1 & 6.88 & 3.43 & 2.00 \\
HT-3 & 5.37 & 2.82 & 1.90 \\
HT-5 & 5.43 & 2.81 & 1.93 \\
HT-7 & 5.25 & 2.76 & 1.90 \\
HT-9 & 6.47 & 3.33 & 1.94 \\
\hline
\end{tabular}




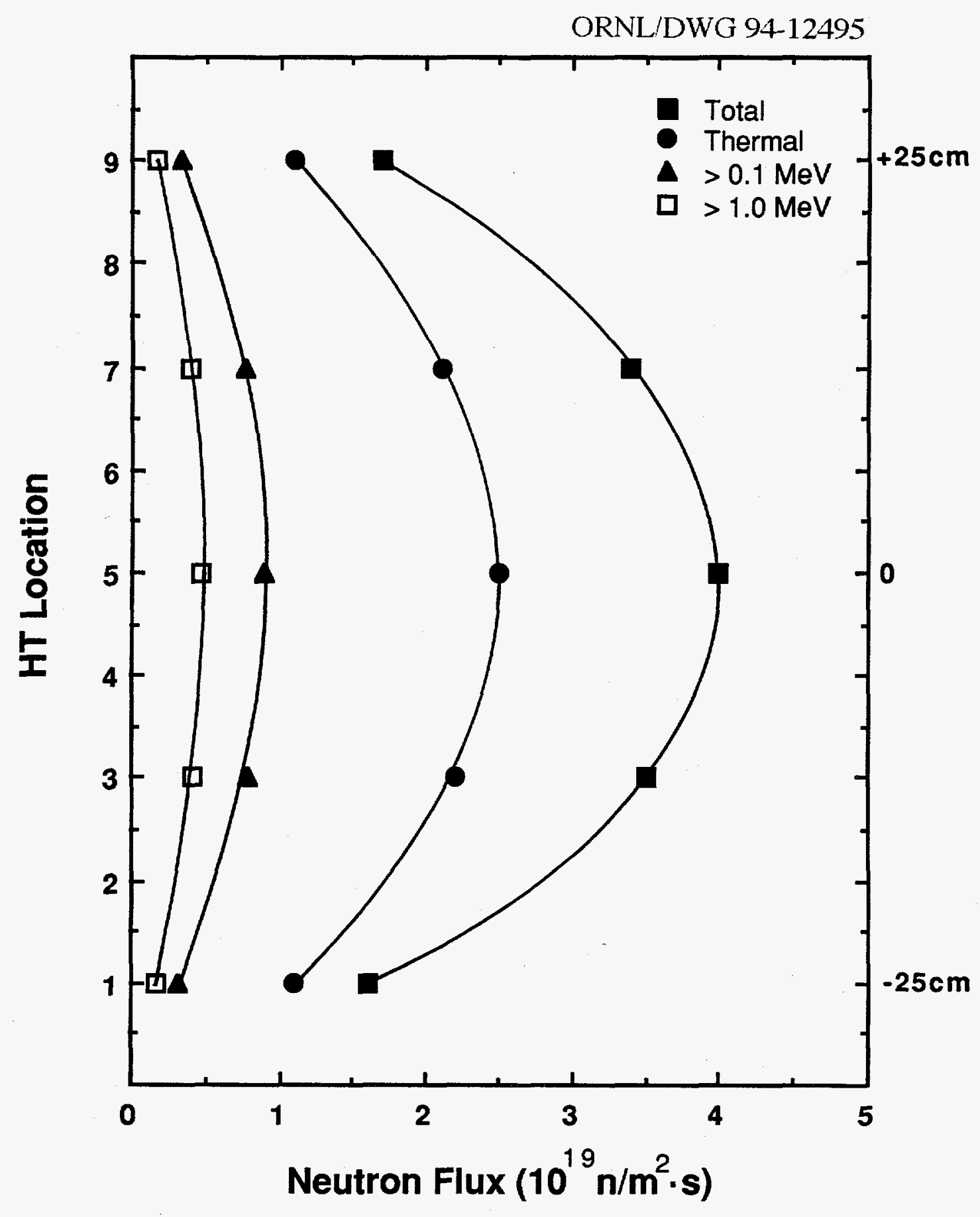

Fig. 4. Measured neutron flux profiles along the length of the hydraulic tube. 


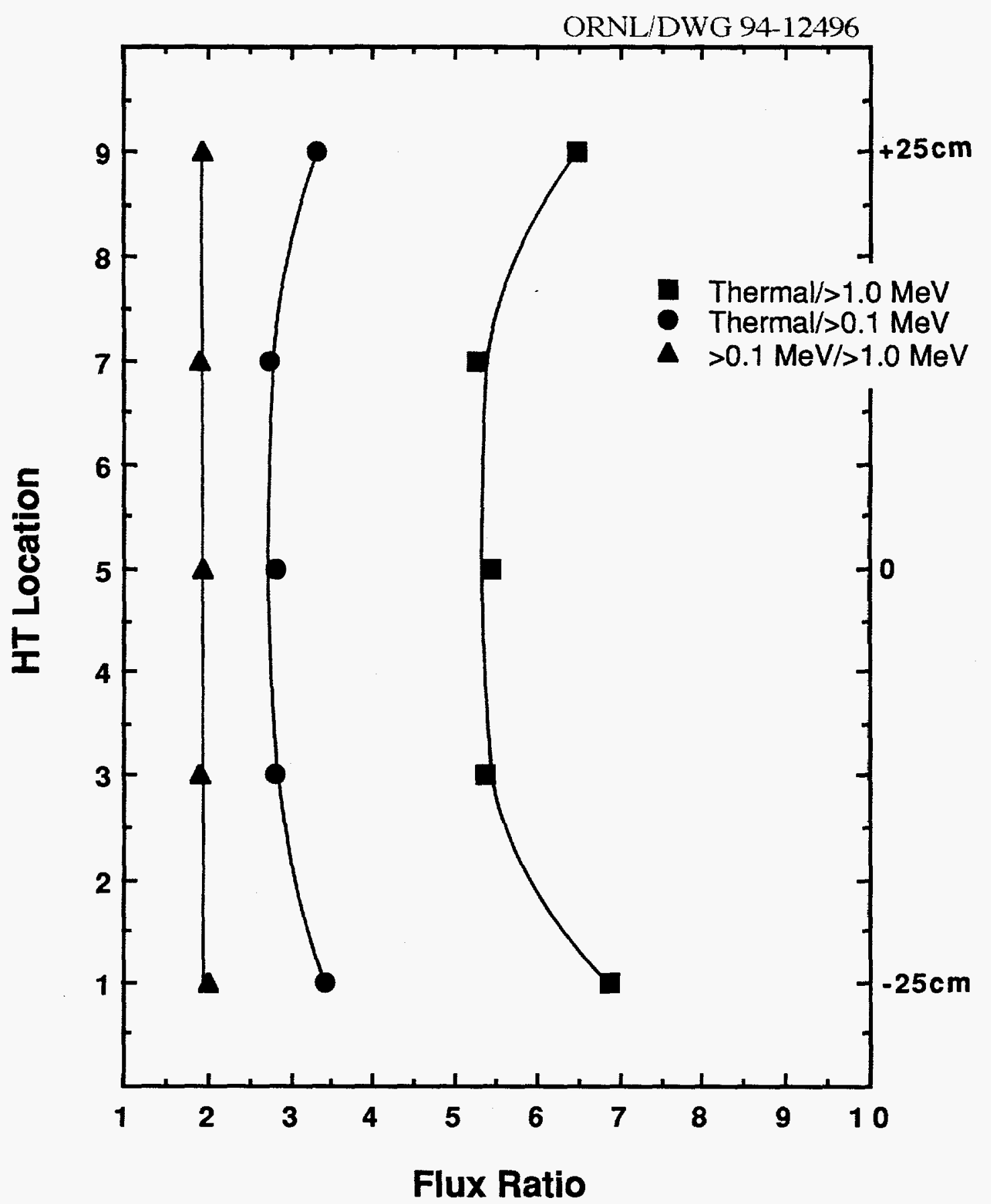

Fig. 5. Some important neutron flux ratios along the length of the hydraulic tube. 
Since two alpha particles (helium nuclei) are produced in each reaction, the reaction cross sections in the ENDF-B files have already been multiplied by two and are listed as helium production cross sections that should not be confused with the reaction cross sections. These helium production cross sections were used in combination with the measured helium concentrations to determine total and fast fluxes.

Gamma fields will also create reaction products in fission monitors and in the Be HAFM via $(\gamma, f)$ and $(\gamma, n) \alpha$ reactions, respectively. However, the threshold energies are high, $>5.4 \mathrm{MeV}$ for ${ }^{237} \mathrm{~Np}$ and $1.67 \mathrm{MeV}$ for ${ }^{9} \mathrm{Be}$, and the reaction cross sections are small, of the order $1 / 100$ and $1 / 1000$ of those for the neutron reactions. Hence, significant contributions from gamma reactions will occur only when the ratio of high-energy gamma rays to high-energy neutrons is high, $>10$. Very high ratios exist at the HFIR pressure vessel ${ }^{4}$ due to greater attenuation of neutrons than gamma rays in the low- $Z$ beryllium reflector and in the water shield between the core and the vessel, but in the core region, the ratio is close to unity and, hence, the contributions from gamma rays in the hydraulic tube are small for ${ }^{237} \mathrm{~Np}$ and negligible for ${ }^{9} \mathrm{Be}$.

All 12 monitors used in this study yielded very consistent values of the fluxes which, in most cases, are within the expected experimental error. A closer look at total and thermal fluxes measured at five locations shows that in most cases the ${ }^{6} \mathrm{Li}$ and ${ }^{10} \mathrm{~B}$ HAFMs yield thermal fluxes that are consistent with those obtained from the other thermal flux monitors, while the total flux values from these two HAFMs are about $40 \%$ higher than those obtained from other monitors. Since both of these HAFMs are thermal flux monitors, the helium production cross sections for these monitors are very well established in the thermal neutron energy range, while there are large uncertainties in cross sections at the higher neutron energies. These uncertainties are reflected in the cross section when it is averaged over the entire spectrum, increasing the magnitude of error in the measured fluxes.

The total and fast ( $>0.1 \mathrm{MeV}$ and $>1 \mathrm{MeV}$ ) fluxes measured using the ${ }^{237} \mathrm{~Np}$ fission monitor at location HT-1 of the hydraulic tube are about 13 to $15 \%$ higher than those obtained from the other types of monitors. These differences are mainly due to the reasons already mentioned, i.e., contribution from photofissions induced by high-energy photons and thermal neutron fission of ${ }^{239} \mathrm{Pu}$ and ${ }^{238} \mathrm{~Np}$. The measured activities were not corrected for these contributions due to uncertainties in the magnitude of error involved. The total and fast fluxes yielded by the fission monitor at location HT-5 of the hydraulic tube are more consistent with the rest of the monitors mainly due to lower thermal-to-fast flux ratio and the consequent lower gamma-to-neutron flux ratio at that location.

There is a flux peak at the center of the core, as is obvious from the average flux values given in Table 14 and plotted in Fig. 4. The total flux at the top and bottom rabbit positions of the tube is $1.6 \times 10^{19} \mathrm{n} / \mathrm{m}^{2} \cdot \mathrm{s}$, and it increases to $4.0 \times 10^{19} \mathrm{n} / \mathrm{m}^{2} \cdot \mathrm{s}$ at the center. The 
There is a flux peak at the center of the core, as is obvious from the average flux values given in Table 14 and plotted in Fig. 4. The total flux at the top and bottom rabbit positions of the tube is $1.6 \times 10^{19} \mathrm{n} / \mathrm{m}^{2} \cdot \mathrm{s}$, and it increases to $4.0 \times 10^{19} \mathrm{n} / \mathrm{m}^{2} \cdot \mathrm{s}$ at the center. The corresponding values for the thermal flux are $1.1 \times 10^{19} \mathrm{n} / \mathrm{m}^{2} \cdot \mathrm{s}$ and $2.5 \times 10^{19} \mathrm{n} / \mathrm{m}^{2}$.s. As expected, the sub-cadmium flux measured at HT-1 and -5 agrees very well with the thermal flux values. The fast flux $(>0.1 \mathrm{MeV}$ and $>1 \mathrm{MeV}$ ) also exhibits the same type of profile, as shown in Fig. 4. Some important flux ratios, given in Table 15, indicate that the thermal-to-fast ratio is a little higher at the ends of the tube as compared to the center, while the ratio of $>0.1 \mathrm{MeV}$ flux to $>1 \mathrm{MeV}$ stays almost constant at two.

The 12 monitors used in this study have their response ranges in different neutron energy intervals, yet they gave very consistent flux values evaluated using the cross sections averaged over the calculated neutron spectrum, indicating that the calculated spectrum is in close agreement with the actual spectrum in the target region, and any spectrum unfolding exercise will not result in very significant improvements. This conclusion is further supported by the results of a recent investigation of some monitor wires in materials experiments in the target region 22 which show that there are no major spectral changes along the active length of the target, and spectrum unfolding results in virtually no adjustment.

Finally, a comparison of the present flux data with earlier data measured in the hydraulic tube 1,2 is given in Table 16 . The earlier data were obtained at $100-\mathrm{MW}$ power when the tube was located at the center of the target bundle in the presence of many curiumbased targets. The reactor now operates at $85 \mathrm{MW}$ which should reduce the fluxes by $15 \%$. However, the hydraulic tube is now sited closer to the fuel, and the neutron absorption rate in the trap has been altered by the current practice of substituting aluminum components for some of the heavy-element targets. The net effect of these competing factors can be seen in Table 16. The total flux in the hydraulic tube is now reduced by up to $33 \%$ and is more symmetrical from the top to the bottom of the tube. The fast fluxes are reduced by up to $25 \%$ and are more symmetrical, too. The thermal flux appears to be increased by up to $10 \%$ or so.

\section{ACKNOWLEDGMENTS}

The authors acknowledge C. W. Alexander for helpful discussions and for providing some of the monitors and cadmium filters used in this study. 


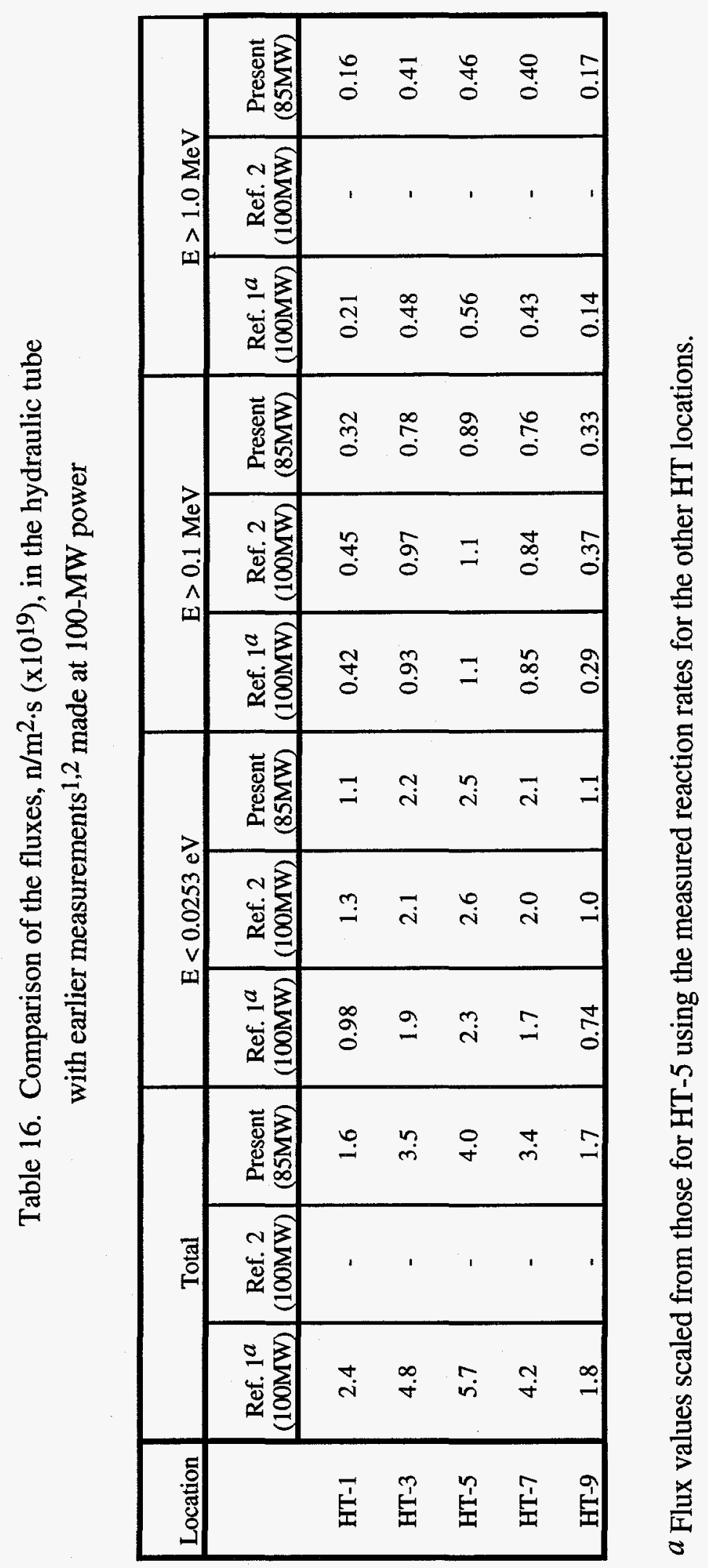




\section{REFERENCES}

1. F. B. K. Kam and J. H. Swanks, Neutron Flux Spectrum in the HFIR Target Region, ORNLTM-3322, Union Carbide Corp. Nuclear Div., Oak Ridge Natl. Lab., March 1971.

2. K. Farrell to E. E. Bloom, intra-Laboratory correspondence, describing 1974 data measured by F. B. K. Kam, J. H. Swanks, K. Farrell, Oak Ridge Natl. Lab., June 10, 1975.

3. K. Farrell, et al., The DOS1 Neutron Dosimetry Experiment at the HB-4-A Key 7 Surveillance Site on the HFIR Pressure Vessel, ORNL/TM-12511, Martin Marietta Energy Systems, Inc., Oak Ridge Natl. Lab., January 1994.

4. I. Remec and F. B. Kam, Neutron Spectra at Different High Flux Isotope Reactor (HFIR) Pressure Vessel Surveillance Locations, NUREG/CR-6117, ORNL/TM-12484, Martin Marietta Energy Systems, Inc., Oak Ridge Natl. Lab., December 1993.

5. "Test Method for Application and Analysis of Helium Accumulation Fluence Monitors for Reactor Vessel Surveillance, E 706 (IIIC)," ASTM E 910-89, 1992 Annual Book of ASTM Standards, Vol. 12.02, American Society for Testing and Materials, New York, 1992.

6. "General Methods for Detector Calibration and Analysis of Radionuclides," ASTM E 181-82 (1991), 1992 Annual Book of ASTM Standards, Vol. 12.02, American Society for Testing and Materials, New York, 1992.

7. "Terminology Relating to Radiation Measurements and Dosimetry," ASTM E 170-92, 1992 Annual Book of ASTM Standards, Vol. 12.02, American Society for Testing and Materials, New York, 1992.

8. "Practice for Determining Neutron Fluence Rate, Fluence, and Spectra by Radioactivation Techniques," ASTM E 261-90, 1992 Annual Book of ASTM Standards, Vol. 12.02, American Society for Testing and Materials, New York, 1992.

9. "Method for determining Thermal Neutron Reaction and Fluence Rates by Radioactivation Techniques," ASTM E 262-86 (1991), 1992 Annual Book of ASTM Standards, Vol. 12.02, American Society for Testing and Materials, New York, 1992.

10. "Test Method for Measuring Fast Neutron Reaction Rates by Radioactivation of Iron," ASTM E 263-88, 1992 Annual Book of ASTM Standards, Vol. 12.02, American Society for Testing and Materials, New York, 1992.

11. "Test Method for Measuring Fast Neutron Reaction Rates by Radioactivation of Nickel," ASTM E 264-87, 1992 Annual Book of ASTM Standards, Vol. 12.02, American Society for Testing and Materials, New York, 1992.

12. "Test Method for Measuring Fast Neutron Reaction Rates by Radioactivation of Aluminum," ASTM E 266-87, 1992 Annual Book of ASTM Standards, Vol. 12.02, American Society for Testing and Materials, New York, 1992.

13. "Test Method for Measuring Neutron Fluence Rate by Radioactivation of Cobalt and Silver," ASTM E 481-86 (1991), 1992 Annual Book of ASTM Standards, Vol. 12.02, American Society for Testing and Materials, New York, 1992. 
14. "Test Method for Measuring Fast Neutron Reaction Rates by Radioactivation of Copper," ASTM E 523-87, 1992 Annual Book of ASTM Standards, Vol. 12.02, American Society for Testing and Materials, New York, 1992.

15. "Test Method for Measuring Fast Neutron Reaction Rates by Radioactivation of Titanium," ASTM E 526-87, 1992 Annual Book of ASTM Standards, Vol. 12.02, American Society for Testing and Materials, New York, 1992.

16. "Standard Test Method for Measuring Reaction Rates by Analysis of Barium-140 from Fission Dosimeters," ASTM E 393-90, 1992 Annual Book of ASTM Standards, Vol. 12.02, American Society for Testing and Materials, New York, 1992.

17. W. W. Engle, "RZ Base Case, Shielding Input to the HFIR SAR," EPM.HFIR.91.001, Oak Ridge Natl. Lab., June 1991.

18. W. E. Ford III, et al., ANSL-V: ENDF/B-V Based Multigroup Cross Section Libraries for Advanced Neutron Source (ANS) Reactor Studies, ORNL-6618, Martin Marietta Energy Systems, Inc., Oak Ridge Natl. Lab., September 1990.

19. W. A. Rhoades and R. L. Childs, "The DORT Two-Dimensional Discrete Ordinates Transport Code," Nucl. Sci. Eng. 99(1) 88-89 (May 1988).

20. J. V. Pace III, "CRES," Oak Ridge Natl. Lab., unpublished cross section averaging code, 1992.

21. W. L. Zijp, et al., DOSDAM84 - Multigroup Cross Sections in SAND-II Format for Spectral, Integral, and Damage Analyses, DLC-131, Radiation Shielding Information Center, Oak Ridge Natl. Lab., 1987.

22. Letter report, L. R. Greenwood, Battelle Northwest Laboratories, to D. J. Alexander, Oak Ridge Natl. Lab., July 2, 1993. 


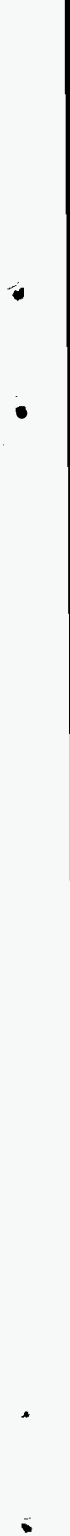


ORNL/TM-12831

\section{INTERNAL DISTRIBUTION}

1-2. Central Research Library

3. Document Reference Section

4-5. Laboratory Records Department

6. Laboratory Records Department, RC

7. ORNL Patent Section

8-10. M\&C Records Office

11. C. A. Baldwin

12. P. F. Becher

13. J. A. Chapman

14. R. D. Cheverton

15. R. H. Cooper, Jr.

16. G. L. Copeland

17. W. R. Corwin

18. D. F. Craig

19. F. F. Dyer

20. K. F. Eckerman

21-23. K. Farrell

24. G. F. Flanagan

25. W. A. Gabbard

26. M. L. Grossbeck

27. D. W. Heatherly

28. R. W. Hobbs

29. F. B. K. Kam

30. L. L. Horton

31. T. J. Huxford
32. H. T. Kerr

33. J. R. Keiser

34. E. H. Krieg, Jr.

35-37. S. T. Mahmood

38. L. K. Mansur

39. D. W. McDonald

40. J. G. Merkle

41-42. S. Mirzadeh

43. B. F. Myers, Jr.

44. R. K. Nanstad

45. J. V. Pace, III

46. J. E. Pawel

47. R. E. Pawel

48. L. Robinson

49. D. L. Selby

50. C. S. Sims

51. L. L. Snead

52-53. R. E. Stoller

54. L. J. Turner

55. R. M. Westfall

56. S. J. Zinkle

57. H. W. Foglesong (Consultant)

58. E. L. Menger (Consultant)

59. J. G. Simon (Consultant)

60. K. E. Spear (Consultant)

EXTERNAL DISTRIBUTION

61. ATOMIC ENERGY OF CANADA, LTD., Chalk River Nuclear Laboratories, Chalk River, Ontario, Canada KOJ 1JO

L. M. Howe

62. BATTELLE NORTHWEST LABORATORIES, Richland, WA 99352

L. R. Greenwood 
63-66. BROOKHAVEN NATIONAL LABORATORY, Materials Department, 76 Cornell, Upton, NY 11973

N. Holden

J. O'Conor

D. Rorer

P. R. Tichler

67. EG\&G IDAHO, INC., P.O. Box 1625, Idaho Falls, ID 83415

J. W. Rogers

68. HANFORD ENGINEERING DEVELOPMENT LABORATORY, P. O. Box 1970, Richland, WA 99352

M. L. Hamilton

69. JAPAN ATOMIC ENERGY RESEARCH INSTITUTE, Department of Fuels and Materials Research, Tokai-mura, Ibaraki-ken, 319-11 Japan

70. MATERIALS ENGINEERING ASSOCIATES, 9700B Martin Luther King, Jr., Highway, Lanham, MD 20706

71. NATIONAL INSTITUTE OF STANDARDS AND TECHNOLOGY, Gaithersburg, MD 20899

D. E. McGary

72-76. NRC, RES/Division of Engineering, Washington DC 20555
A. Hiser (MS NS 217C)
S. N. Malik (MS NS 217C)
M. E. Mayfield (MS NS 217C)
C. Z. Serpan (MS NS 217C)
A. Taboda (MS NS 217C)

77. ROCKWELL INTERNATIONAL CORPORATION, Canoga Park, CA 91303

B. M. Oliver

78-79. UNIVERSITY OF CALIFORNIA, Department of Chemical and Nuclear Engineering, Ward Memorial Drive, Santa Barbara, CA 93106

G. E. Lucas

G. R. Odette

80. WESTINGHOUSE SAVANNAH RIVER COMPANY, Savannah River Laboratory, Aiken, SC 29808

M. R. Louthan, Jr. 
81. DOE, Division of Magnetic Fusion Energy, Washington, DC 20545

F. W. Wiffen (ER-543, J224/GTN)

82-86. DOE, Division of Materials Sciences, Washington, DC 20545

Y. Chen (ER-131, J321/GTN)

A. L. Dragoo (ER-131, F240/GTN)

R. J. Gottschall (ER-131, J321/GTN)

H. Kerch (ER-131, J321/GTN)

I. L. Thomas (ER-132, J321/GTN)

87. DOE, Office of Fossil Energy, Washington, DC 20545

M. I. Singer (FE-14, B115/GTN)

88. DOE, OAK RIDGE OPERATIONS OFFICE, P.O. Box 2001, Oak Ridge, TN 37831-8600

Office of Assistant Manager for Energy Research and Development

89-90. DOE, OFFICE OF SCIENTIFIC AND TECHNICAL INFORMATION, P.O. Box 62, Oak Ridge, TN 37831

For distribution as shown in DOE/OSTI-4500, Distribution Category UC-404 (Materials) 